\title{
The Therapeutic Potential of Anti-Inflammatory Exerkines in the Treatment of Atherosclerosis
}

\author{
Megan $\mathrm{Yu}^{1, *}$, Sheng-Feng Tsai ${ }^{2}$ and Yu-Min Kuo ${ }^{2,3}$ \\ 1 Department of Chemistry, University of Virginia, Charlottesville, VA 22904, USA \\ 2 Institute of Basic Medical Sciences, National Cheng Kung University, Tainan 70101, Taiwan; \\ eric04142000@hotmail.com (S.-F.T.); kuoym@mail.ncku.edu.tw (Y.-M.K.) \\ 3 Department of Cell Biology and Anatomy, National Cheng Kung University, Tainan 70101, Taiwan \\ * Correspondence: ymeganyu@gmail.com
}

Received: 17 March 2017; Accepted: 9 June 2017; Published: 13 June 2017

\begin{abstract}
Although many cardiovascular (CVD) medications, such as antithrombotics, statins, and antihypertensives, have been identified to treat atherosclerosis, at most, many of these therapeutic agents only delay its progression. A growing body of evidence suggests physical exercise could be implemented as a non-pharmacologic treatment due to its pro-metabolic, multisystemic, and anti-inflammatory benefits. Specifically, it has been discovered that certain anti-inflammatory peptides, metabolites, and RNA species (collectively termed "exerkines") are released in response to exercise that could facilitate these benefits and could serve as potential therapeutic targets for atherosclerosis. However, much of the relationship between exercise and these exerkines remains unanswered, and there are several challenges in the discovery and validation of these exerkines. This review primarily highlights major anti-inflammatory exerkines that could serve as potential therapeutic targets for atherosclerosis. To provide some context and comparison for the therapeutic potential of exerkines, the anti-inflammatory, multisystemic benefits of exercise, the basic mechanisms of atherosclerosis, and the limited efficacies of current anti-inflammatory therapeutics for atherosclerosis are briefly summarized. Finally, key challenges and future directions for exploiting these exerkines in the treatment of atherosclerosis are discussed.
\end{abstract}

Keywords: atherosclerosis; exerkine; physical exercise

\section{Introduction}

Atherosclerosis and its clinical manifestations in coronary heart disease, stroke, and peripheral artery disease are the leading cause of morbidity and mortality in the Western world [1]. Understanding the pathophysiology of atherosclerosis and developing potential means of treating the disease are of utmost importance, as it currently accounts for 17.3 million deaths and is expected to increase to more than 23.6 million by 2030 [2]. Although the etiology of atherosclerosis is complex, its development can be characterized into five stages: (1) low-density lipoprotein (LDL) retention in the arterial wall, (2) LDL oxidation and modification, (3) inflammation, (4) formation of foam cells and fibrous plaques, and (5) calcification, plaque rupture, and thrombosis. Briefly, following a high-fat, high-cholesterol diet, lipoproteins and their aggregates accumulate in the subendothelial layer of the arterial wall, followed by the generation of oxidized species that recruit monocytes and T-cells to the vessel wall. These monocytes then transmigrate into the intima, convert into macrophages, and take up lipoproteins, forming foam cells that eventually form fatty streaks-the hallmark of early atherosclerosis [3]. Some of these fatty streaks accumulate smooth muscle cells (SMCs), which secrete fibrous elements that form plaques made of connective tissue. These plaques are eventually substituted with collagen-rich fibrous tissue that undergoes matrix production and degradation, and form fibrous caps that may rupture, calcify, and cause thrombosis [4-6]. 
Atherosclerosis is now primarily considered a chronic inflammatory disease, as the vascular wall hosts many complex chronic inflammation events among various inflammatory molecules [7]. In addition, unstable atherosclerotic plaques are characterized by high levels of inflammatory cells and mediators, including leukotrienes, active proteases, and cytokines [8]. Because approximately two-thirds of heart attacks and strokes are caused by the rupture of an unstable atherosclerotic plaque [8], many anti-inflammatory drugs, such as statins, antithrombotics, and antihypertensives, have been developed to reduce these adverse events. However, these drugs at most only delay the progression of atherosclerosis. Due to its pro-metabolic, multisystemic, and anti-inflammatory benefits, physical exercise has been prescribed as a non-pharmacologic treatment for atherosclerosis, as it boosts high-density lipoprotein (HDL) levels while lowering LDL levels, and reduces the risk of many chronic diseases, including type 2 diabetes and cancer. It also has a number of anti-inflammatory effects, including reducing visceral fat, increasing levels of nitric oxide (NO), and secreting anti-inflammatory exerkines from skeletal muscles and other secretory organs.

Ever since Bente Pedersen and colleagues proposed that contracting skeletal muscle could function in an endocrine-like manner by releasing certain muscle-derived peptides, metabolites, and circulating RNA species (myokines), there has been increasing interest in identifying and exploiting their therapeutic potential [9]. Later, it has been found that these circulating cytokines and humoral factors do not merely originate from skeletal muscle; they are also secreted by adipose tissue (adipokines), the liver (hepatokines), and other secretory organs. Therefore, Mark Tarnopolsky and colleagues coined the term "exerkines" in 2016 to collectively describe these circulating species that are produced and secreted by any tissue or organ into the circulation and could facilitate the multisystemic benefits of exercise [10]. These exerkines are found in extracellular vesicles that either bud outwardly from the plasma membrane (microvesicles; 100-1000 nm in diameter) or originate from the exocytosis of multivesicular bodies (exosomes; 20-140 nm in diameter) [10]. Our focus of this review is to highlight major anti-inflammatory exerkines that could serve as potential therapeutic targets for atherosclerosis. We also briefly summarize the anti-inflammatory, multisystemic effects of exercise, the basic mechanisms of atherosclerosis, and the limited efficacies of current anti-inflammatory therapeutics for atherosclerosis to provide some context and comparison to the therapeutic potential of these anti-inflammatory exerkines. Finally, we discuss key challenges and future directions for deploying these exerkines in the clinic. Understanding the role of exercise and exerkines in the prevention of atherosclerosis may lead to future development of bioengineered targets in the treatment of atherosclerosis.

\section{Basic Mechanisms of Atherosclerosis}

\subsection{LDL Retention in Arterial Wall}

Atherosclerotic development usually begins with LDL accumulation in the subendothelial matrix of the artery. Seminal findings that atherosclerosis is induced by LDL receptor mutations provide strong evidence that elevations in LDL levels are sufficient to initiate atherosclerosis [11,12]. Lesions usually form in regions with arterial branching or curvature, as they have disturbed flow, a high oscillatory sheer index, and low endothelial shear stress [12]. Endothelial cells in atherosclerosis-resistant regions have an ellipsoidal structure and nuclear morphology and coaxial alignment in the primary flow direction whereas those in atherosclerosis-prone regions do not display an orderly pattern and have a cuboidal shape [13]. Endothelial cells exposed to atheroprotective or atheroprone regions may also "mark" their DNA, creating unique flow-dependent epigenetic landscapes [13,14]. Some biomarker candidates that could facilitate the mechanotransductive property of endothelial cells include platelet and endothelial cell adhesion molecule 1 (PECAM-1) in complex with vascular endothelial cadherin (VE-cadherin) and vascular endothelial growth factor 2 (VEGFR2) [15], G protein-coupled S1P1 (S1P receptor-1) [16], Piezo1 [17], and syndecan 4 [18]. LDL diffuses passively through endothelial cell junctions, and the interaction between LDL constituent apolipoprotein B (ApoB) and matrix proteoglycans seem to permit its retention in the artery. Other ApoB-containing lipoproteins, such as lipoprotein(a), also accumulate in the intima and appear to be particularly atherogenic due to their effects on angiogenesis, fibrinolysis, and SMC growth [19-21]. 


\subsection{LDL Oxidation and Modification}

As LDL is trapped in the arterial wall, arterial cells release oxidative products that can induce lipid oxidation. This process is thought to occur in two steps. First, lipids in LDL are oxidized with little change in ApoB. Then, when monocytes are recruited to the lesion and transform into macrophages, the protein portion of LDL is modified while the lipids in LDL continue to be oxidized, causing a loss of recognition by the LDL receptor [22]. This change causes cellular uptake of LDL by receptors that are not regulated by cholesterol levels, leading to an accumulation of cholesterol-loaded cells, or foam cells [23], that further promotes inflammation by inducing monocytes and lymphocytes but not neutrophils that bind to endothelial cells.

Trapped LDL also undergoes other modifications that contribute to inflammation and foam cell formation, such as lipolysis, proteolysis, and aggregation [24]. Unlike LDL, it was originally thought HDL could prevent atherosclerosis due to its anti-oxidative, anti-inflammatory, antithrombotic, and profibrinolytic effects and by removing excess cholesterol from peripheral tissues inhibiting lipoprotein oxidation [25]. These effects are mainly caused by serum paraoxonase, an esterase on HDL that can degrade certain biologically active oxidized phospholipids [26]. However, recent findings have suggested HDL is impaired in patients with diabetes, coronary disease, chronic renal insufficiency, CVD risk factors and disorders, and patients who experienced coronary angiography but not in healthy individuals [27-34]. Specifically, the inverse correlation between HDL levels and the risk of future CVD events in healthy individuals may not apply and may, in fact, be abolished. HDL from these patient populations has also been found to have no protective vascular effects or could even cause paradoxical harmful effects [34]. This may be caused by significant changes in their pathological structure in an acute-phase reaction, during which HDL is characterized by increased concentrations of serum amyloid A, type 2 secretory phospholipase A2, and ceruloplasmin, and lower concentrations of apolipoprotein A1 [33].

\subsection{Inflammation}

Mild LDL oxidation causes monocyte and lymphocyte recruitment to the arterial wall by stimulating extracellular cells to produce several pro-inflammatory adhesion molecules and monocyte activators, such as macrophage colony-stimulating factor (M-CSF), monocyte chemoattractant protein 1 (MCP-1), and growth-related oncogene (GRO) [35]. In mice studies, Ly6 ${ }^{\text {hi }}$ monocytes most readily enter developing atherosclerotic lesions, but atherosclerosis is maximally inhibited only when Ly $6^{\text {hi }}$ and Ly6 $6^{\text {lo }}$ monocytes are blocked [36]. Steps that enhance the proliferation of bone marrow-derived hematopoietic stem cells, such as cholesterol accumulation from defective cholesterol efflux, increase circulating monocytes and promote atherosclerosis $[13,37]$. Through a $\mathrm{G}$ protein-mediating mechanism, mildly-oxidized LDL elevates cAMP levels that decrease the expression of endothelial cell leukocyte adhesion molecule-1 (ELAM-1), and increase the expression of M-CSF, MCP-1, and GRO [38]. This process increases gene transcription rates and stabilizes the mRNA of these genes. Leukocyte adhesion is mediated by selectins that bind to carbohydrate ligands on leukocytes, and several adhesion molecules, including intercellular adhesion molecule-1 (ICAM-1), P-selectin, E-selectin, platelet endothelial cell adhesion molecule-1 (PCAM-1), and vascular cell adhesion protein 1 (VCAM-1), are critical for their recruitment [39]. Inflammasome activation is also found in atherosclerotic lesions, which involves cholesterol microcrystals from the cellular ingestion of retained lipoproteins and interleukin-1 $\beta$ (IL-1 $\beta$ ) [40,41].

Oxidized LDL could also inhibit endothelin expression and nitric oxide (NO) production. This results in vasodilation reduction, as NO has been shown to be anti-atherogenic [42].

\subsection{Formation of Foam Cells and Fibrous Plaques}

Before being taken up by macrophages to form foam cells, LDL must be highly oxidized. This process involves reactive oxygen species (ROS) and enzymes that produce highly reactive species and promote LDL oxidation. For instance, myeloperoxidase generates hypochlorous acid and tyrosyl 
radicals while sphingomyelinase promotes lipoprotein aggregation. Secretory phospholipase (group II sPLA2) also promotes LDL oxidation [43,44]. Oxidized LDL is then recognized by macrophage scavenger receptors, such as SR-A, CD-36, and CD69, leading to foam cell formation [45]. These foam cells often accumulate in the proteoglycan layer of the intima and often appear as yellow-colored xanthomas or fatty streaks.

While many fatty streaks do not progress further, some become worse over time, especially those at predilection sites. In some areas, acellular, lipid-rich material accumulates in the intima without disrupting its structure. In other areas, the lipid pools grow into a large mass of extracellular lipid and promote the accumulation of SMCs and its extracellular matrix that contribute to the necrotic core of the intima. This process leaves a pool of lipids behind, such as cholesterol esters from LDL, free cholesterol-rich erythrocyte membranes from intraplaque hemorrhages, and cell debris devoid of a matrix [46]. Over time, the arterial intima is replaced with collagen-rich fibrous tissue, which is mainly produced by SMCs containing numerous rough endoplasmic reticulum and Golgi complexes. These SMCs are unique as they have undergone phenotypic modulation to the synthetic phenotype, and they accumulate substantially during lesion development $[47,48]$. They also downregulate expression of differentiation marker genes, such as those encoding muscle $\alpha$-actin (Acta2) and smooth muscle myosin heavy chain (Myh11), thus increasing their production of extracellular matrix, proteoglycans, and proteins that are beneficial in outward vessel remodeling and plaque stabilization [13,49].

Circulating progenitor cells, multipotent stem cells in the media or adventitia, and synthetic SMCs in the arterial media are other possible sources of plaque SMCs [50]. However, some of these findings have been contested, and more research is needed to investigate the origin of plaque SMCs.

\subsection{Calcification, Plaque Rupture, and Thrombosis}

With increasing age and time, atherosclerotic lesions could result in calcification. Apoptotic cells, extracellular matrix, and necrotic core material are common sources of these calcification sites, and these sites can expand to form larger lumps of calcium deposits over time [31]. Many of these plaques often exclusively comprise of fibrous and calcified tissue without extracellular lipid pools or a necrotic core [51]. Plaque necrosis has been found to result from lesional macrophage apoptosis and defective efferocytosis, leading to post-apoptotic necrosis, loss of efferocytosis-mediated anti-inflammatory signaling, and generation of damage-associated molecular patterns (DAMPs) [13]. Receptor-interacting protein 3 (RIP3)-mediated necrosis may also play a role in this process [52]. Advanced lesional macrophage apoptosis is likely induced by many factors, such as oxidized lipoproteins, oxidized phospholipids, and accumulation of lipoprotein-derived cholesterol in the ER. Both macrophage apoptosis and defective efferocytosis are currently thought to result from compromised expression of mediators of atherosclerotic lesions and the amplification of major inflammatory events in atherosclerosis [13]. For example, the MerTK tyrosine oncogene, which is critical in lesional efferocytosis, could be cleaved when triggered by inflammation, thus possibly contributing to defective efferocytosis in advanced lesions [13].

Over time, some of these plaques could rupture and cause thrombosis. These ruptures often occur in the presence of a structural defect in the fibrous cap that is induced by inflammation, as these defects could cause pulsatile changes in arterial blood pressure. Plaque ruptures often occur at the edges of lesions, which are rich with foam cells, suggesting they contribute not only to inflammation but also thrombosis [53]. Thinning of the fibrous caps could occur in two possible ways: (1) the gradual loss of SMCs from the fibrous cap and (2) the degradation of the collagen-rich cap matrix by macrophages [54]. Ruptured fibrous caps contain fewer SMCs and less collagen than intact caps, and macrophage foam cells secrete proteolytic enzymes that degrade the fibrous cap, such as plasminogen activators, cathepsins, and matrix metalloproteinases [55]. A causal relationship between plaque rupture and thrombosis may exist, as dislodged plaques are often found within the thrombus. Plaque erosion is also often associated with thrombosis. 


\section{Anti-Inflammatory Effects of Exercise on Atherosclerosis}

Because many existing therapeutics for atherosclerosis may not be completely effective and at most only delay the onset of atherosclerosis, there is a considerable interest in utilizing exercise as a possible non-pharmacologic treatment. Unlike anti-inflammatory therapeutics, physical exercise increases energy expenditure, promotes longevity, and helps patients reduce the risk for many chronic diseases [9]. As physical exercise can be used by many people in the general population, it should be promoted in the treatment of atherosclerosis.

Many studies and reviews have discussed numerous mechanisms that could facilitate the anti-inflammatory effects of exercise, such as the reduction of visceral fat, the reduction of pro-inflammatory monocytes and Toll-like receptors (TLRs) on monocytes and macrophages, and the increased production of anti-inflammatory exerkines from skeletal muscles and other secretory organs [56-58]. These mechanisms could be applied to the treatment of atherosclerosis, as atherosclerosis has many features similar to those of other chronic inflammatory diseases, such as Type 2 diabetes and RA. We thus devote this section to briefly discuss the mechanisms that bring about the anti-inflammatory effects of exercise. Major anti-inflammatory exerkines that could serve as potential therapeutic targets for atherosclerosis are discussed in the next section.

\subsection{Reduction of Visceral Fat}

Increases in visceral fat have been associated with increased mortality and risk of many diseases, including atherosclerosis and Type 2 diabetes. As physical exercise brings about a reduction in visceral fat and increases energy expenditure, it subsequently results in lower production of pro-inflammatory adipokines, including tumor necrosis factor (TNF), leptin, retinol-binding protein 4, lipocalin 2, interleukin-6 (IL-6), interleukin-18 (IL-18), CC-chemokine ligand 2 (CCL2 or MCP-1), CXC-chemokine ligand 5, and angiopoietin-like protein 2 and an increase in anti-inflammatory cytokines, such as adiponectin and secreted frizzled-related protein $5[9,59]$. Through a decrease in pro-inflammatory adipokines and fat deposits, exercise brings about a decrease in atherosclerotic risk and systemic inflammation.

\subsection{Reduction of Pro-Inflammatory Monocytes and Regulatory T Cells in Circulation}

There are two major types of monocytes: classical $\left(\mathrm{CD} 14^{\text {hi }} \mathrm{CD} 16^{-}\right)$and non-classical $\left(\mathrm{CD} 14^{\text {low }} \mathrm{CD} 16^{+}\right.$ or $\mathrm{CD} 14^{\text {hi }} \mathrm{CD} 16^{+}$) monocytes, with the major difference being that inflammatory $\mathrm{CD} 14^{\text {low }} \mathrm{CD} 16^{+}$ monocytes express about 2.5 times more TLR4 on the cell surface than the other types of monocytes [60]. Despite constituting $10 \%$ of all monocytes [61], inflammatory monocytes could play a critical role in the inflammation of many diseases, including atherosclerosis and diabetes, due to their heightened antigen-presenting ability and capability to secrete higher levels of pro-inflammatory cytokines [13]. While short, individual bouts of exercise have been shown to have little effect on the number of inflammatory monocytes [62], regular exercise appears to reduce the proportion of inflammatory monocytes in the circulation. A cross-sectional analysis of age-matched healthy, physically inactive elderly men and women and physically active subjects who had 12 weeks of exercise demonstrated a $64 \%$ decrease in the percentage of inflammatory monocytes in physically inactive subjects following the training intervention [63]. In addition, high-intensity aerobic exercise could elevate regulatory $\mathrm{T}$ cell levels, reduce pro-inflammatory cytokines, and increase anti-inflammatory cytokine levels $[9,64]$. Acute and chronic exercise has also been found to downregulate TLR1, TLR2, and TLR4 expression on these monocytes. Specifically, acute exercise has been found to reduce TLR4 expression by $32 \%$ after one and a half hours of cycling and TLR2 expression by $12 \%$ only on pro-inflammatory monocytes [65]. Results from a 12-week chronic exercise training program also demonstrated TLR4 expression on inflammatory monocytes was significantly lower in younger and older participants [66].

\subsection{Increased Levels of $\mathrm{NO}$}

Physical exercise could also exert anti-inflammatory effects by increasing NO levels. Mice studies have suggested that in hyperlipidemic mice, moderate aerobic exercise increases plasma levels of NO 
and endothelial NO synthase expression through murine macrophages, which can confer vascular protection and scavenge ROS $[67,68]$. However, prolonged strenuous physical exercise can reduce cyclic pulsations, thereby limiting NO production $[67,68]$. Therefore, moderate exercise should be used in the prevention of atherosclerosis, as it increases NO levels.

\subsection{Inhibition of Monocyte and Macrophage Infiltration into Adipose Tissue}

Another possible mechanism that facilitates the anti-inflammatory effects of exercise is the inhibition of monocyte and macrophage infiltration into adipose tissue. Macrophages and $\mathrm{T}$ cells that infiltrate adipose tissue are known to regulate its inflammatory state [69], and CCL2 and CCL3 may stimulate the recruitment of macrophages [70]. Therefore, the migration of peripheral blood mononuclear cells to inflamed sites may play a role in the development of atherosclerosis [71]. Mice studies have also demonstrated that exercise could decrease the expression of ICAM- 1 in tissues, which is known to have a role in the adhesion of inflammatory cells to vascular endothelium and mediates interactions between $\mathrm{T}$ cells and target cells [72]. ICAM-1 expression increases with obesity in humans [72], and blocking its expression in obese mice prevented macrophage infiltration into adipose tissue [72]. Therefore, ICAM-1 may have a role in the reduction of macrophage infiltration into adipose tissue.

\subsection{Phenotypic Switching of Macrophages Within Adipose Tissue}

Phenotypic switching of macrophages within adipose tissue could also facilitate the anti-inflammatory effects of exercise. Animal studies have demonstrated inflamed adipose tissue is associated with the recruitment of M1-type macrophages or a phenotypic switch from M1- to M2- type macrophages [73]. M-1, or classically activated, macrophages produce pro-inflammatory molecules, such as TNF, IL-6, inhaled $\mathrm{NO}$ (iNO), and NO, and are induced by cytokines released by Type-1 helper T (Th1) cells, such as INF- $\gamma$, and TLR ligands 159]. They also produce interleukin-12 (IL-12), which is critical for the expansion of Th1 cells and the synthesis of INF- $\gamma$. M-2, or alternatively activated, macrophages produce anti-inflammatory cytokines, decrease the production of inflammatory cytokines, and up-regulate the expression of arginase 1, mannose receptor 1, and interleukin-1 receptor antagonist (IL-1ra) [59]. They also synthesize IL-12, which stimulates the expansion of Type-2 helper T (Th2) cells and the expression of IL-4 and interleukin-13 (IL-13). Rodent studies have also demonstrated chronic exercise could downregulate the expression of the M1-specific marker CD11c and TL4 in adipose tissue, which could trigger phenotype switching from the M1- to M2-phenotype [58]. Similar conclusions were attained in a human exercise study that demonstrated a rise in expression of the M2-specific markers CD14, AMAC1, and MR, and a decline in the expression of the M-1 specific markers IL-6, TNF- $\alpha$, and MCP-1 [74]. Collectively, these findings suggest that regular exercise might favor the M-2 macrophage phenotype.

\subsection{Enhanced Secretion of Glucocorticoids and Catecholamines}

Physical exercise could also induce cortisol production from cholesterol, as its effects are transmitted to the hypothalamus that promotes the production of ACTH in the adrenal gland [75]. In addition to preserving blood pressure, cortisol could produce glucose based on proteins and promote lipometabolism and muscle function [76]. Adrenaline and noradrenaline are also produced by the adrenal medulla in response to exercise. Collectively, these glucocorticoids could block the synthesis of pro-inflammatory cytokines, such as IL-12 and TNF- $\alpha$, by binding to their receptors on monocytes and macrophages and inducing a shift from a TH1 cell to a humoral Th2 immune response [77]. IFN- $\gamma$ and IL-2 levels subsequently decline while interleukin-4 (IL-4) and interleukin-10 (IL-10) levels increase, even though they do not directly influence IL-10 production [77]. Catecholamines, such as epinephrine and norepinephrine, directly promote the synthesis of IL-10 and hinder IL-12 production without directly influencing Th2 cells $[77,78]$.

\section{Anti-Inflammatory Exerkines in the Treatment of Atherosclerosis}

Another major mechanism that facilitates the anti-inflammatory effects of exercise is the release of anti-inflammatory exerkines into the circulation. Since the discovery that circulating cytokines and 
humoral factors are secreted not only by skeletal muscle but also by other secretory organs, there has been considerable interest in exploiting their therapeutic potential, as they could be used in many patient populations. In this section, although we define these exerkines to originate from any secretory organ, many of the potential anti-inflammatory exerkines for atherosclerosis that have available data to date are mostly secreted by skeletal muscle and adipose tissue. While there could be other exerkines that have anti-atherogenic effects, such as IL-10, they were not mentioned here as the exerkine field is still rapidly expanding and little data is currently available regarding their abilities to facilitate the effects of exercise. Where available, the intensity, type, and duration of exercise are also considered in this section.

\subsection{Irisin}

Irisin, a 12,587 Da hormone-like polypeptide with 112 amino acids, is synthesized in muscle tissue after the proteolytic cleavage of its precursor, the membrane protein fibronectin type III domain-containing protein 5 (FNDC5). With an N-terminal fibronectin type III-like domain that forms a continuous intersubunit $\beta$-sheet dimer and a flexible $C$-terminal tail, it is prone to dimerization without the influence of glycosylation, suggesting irisin activates its receptor through the irisin domain as a myokine ligand or as a paracrine or autocrine dimerization module on FNDC5-like receptors [79]. Many studies have demonstrated irisin stimulates the browning of white adipocytes, which increases their metabolic rates [80-82]. This finding led many investigators to hypothesize irisin levels would be lower in individuals with metabolic disorders. Indeed, this was confirmed in many clinical studies comparing patients with Type 2 diabetes, insulin resistance, and other metabolic syndromes with controls. Additionally, irisin improves energy consumption and at pharmacological concentrations (50-100 nmol/L), it enhances the proliferation capacity of hippocampal neurons and reduces their damage from neurodegenerative diseases [83]. As atherosclerosis has many features similar to those of other chronic inflammatory disorders, recent results from a carotid partial ligation model of apolipoprotein E (ApoE)-deficient mice fed on a high-cholesterol diet demonstrated irisin significantly suppressed carotid neointima formation and promoted human umbilical vein endothelial cell survival by upregulating microRNA126-5p expression through the ERK signaling pathway. Blocking microRNA126-5p expression subsequently abolished the inhibitory effects of irisin on neointima formation, lesional lipid deposition, macrophage area, and the endothelial cell proliferation effects $[82,84]$. Results from a separate study utilizing ApoE-deficient mice fed on a high-cholesterol diet and a mouse carotid partial ligation model also demonstrated irisin significantly reduced the severity of aortic atherosclerosis and restored ox-LDL-induced human umbilical vein endothelial cell dysfunction by inhibiting the reactive oxygen species (ROS)/p38 MAPK/NF- $\mathrm{kB}$ signaling pathway cell apoptosis through the upregulation of Bcl-2 and downregulation of Bax and caspase-3 expression [85].

Given its clear anti-inflammatory role in atherosclerosis, multiple studies have attempted to establish a relationship between exercise and irisin levels. Findings from a systematic review and multiple animal and human randomized controlled trials suggested although single bouts of exercise (sessions were about 30 to $45 \mathrm{~min}$ each) led to transient increases in plasma irisin levels, chronic exercise ( 3 to 4 sessions for 8 to 12 weeks) may actually reduce plasma irisin levels [86-89]. This parallels the idea that irisin is a metabolic stress-induced chemokine that transiently increases in response to cellular energy demand [90]. Even though higher intensity exercise may lead to higher irisin levels, with absolute workload exerting the great effect, this effect is transient and might explain irisin's quick return to baseline levels. In fact, a recent study suggested irisin levels remained elevated above baseline for $125 \mathrm{~min}$ after exercise for moderate intensity whereas they returned to baseline just within $15 \mathrm{~min}$ post-exercise for high intensity [91]. Furthermore, resistance exercise appears to induce a greater increase in irisin levels compared to endurance exercise or a combination of them [91]. Although these findings suggest that acute resistance exercise at moderate intensity is most likely to induce higher irisin levels to exert the anti-inflammatory effects of exercise for atherosclerotic patients, further studies are needed to confirm these findings. 


\subsection{Adiponectin}

Human adiponectin contains 244 amino acids and has a collagen-like and a globular C1q-like domain. It has at least three homomeric complexes: trimer, hexamer, and higher order multimers [92]. Plasma levels of adiponectin are inversely correlated with body mass index (BMI), abdominal fat, and weight gain [93]. Through activation of its two receptors, adiponectin receptor 1 (AdipoR1) and adiponectin receptor 2 (AdipoR2), it stimulates insulin secretion, decreases hepatic glucose production, and enhances glucose and fatty acid oxidation in skeletal muscles [94,95]. In various animal model and LPS-stimulated porcine macrophages and tissue experiments, adiponectin has been shown to inhibit the production of pro-inflammatory cytokines, including TNF $\alpha$, IL-6, and IL-1 $\beta$, and increase the production of IL-10 [96-98]. It also increases the effect of NO by activating the AMPK signal pathway through the AdipoR1 and AdipoR2 receptors, thus favoring vasodilation and inhibiting C-reactive protein (CRP) production, platelet aggregation, monocyte adhesion, and smooth muscle proliferation. Additionally, it downregulates the expression of scavenger A receptors and inhibits the conversion of macrophages into foam cells [99]. Through the COX-2-mediated anti-inflammatory and AMPK-mediated anti-apoptotic mechanisms, it also protects the heart from myocardial ischemia-reperfusion injury. Additionally, it attenuates ox-LDL and hyperglycemia-induced ROS generation by activating the cAMP7PKA cascade, reduces atherosclerotic plaque in the abdominal aorta, and blocks the transformation of macrophages to foam cells [100-102].

Due to its clear anti-inflammatory role in atherosclerosis, many studies have attempted to determine the association between exercise and adiponectin levels. Findings from a systematic review and multiple human and animal exercise experiments demonstrated adiponectin levels seem to significantly increase in both obese and healthy subjects after acute (between 30 and 60 min-sessions) and chronic exercise (2 to 4 sessions for 4 to 52 weeks) training, with high-intensity training $\left(75-85 \% \mathrm{VO}_{2}\right.$ peak) generating a greater increase than low-intensity training $\left(50 \% \mathrm{VO}_{2}\right.$ peak) $[98,103,104]$. High-intensity exercise might likely increase adiponectin levels, as results from studies that set exercise protocols at low to moderate intensity $\left(<65 \% \mathrm{VO}_{2 \max }\right)$ showed no change in adiponectin levels $[96,97,105]$. Scarce data is available regarding the effects of resistance training in adiponectin levels; however, de Mello et al. suggested a combination of resistance and endurance exercise could generate a significantly greater increase in adiponectin levels compared to endurance training alone [106]. Together, these findings suggest that high-intensity acute or chronic exercise is most likely to generate higher levels of adiponectin; however, due to the scarcity of data and the low statistical power of available studies, more investigation is needed in this area.

\subsection{IL-6}

Human IL-6 consists of 212 amino acids and has a four-helix bundle structure containing four long $\alpha$-helices arranged in an up-up-down-down topology. It is part of a family of cytokines that plays an important role in immune reactions, metabolic processes, and hematopoiesis [107]. All IL-6-related cytokines, except for IL-31, have the membrane glycoprotein gp130 as a common receptor and signal transducer subunit. The IL-6 receptor (IL-6R) also has an $80 \mathrm{kDa}$ type 1 cytokine $\alpha$-receptor subunit that is largely expressed in hepatocytes, leukocytes, and megakaryocytes [74]. Unlike common pro-inflammatory cytokines, such as interleukin-1 (IL-1) and TNF $\alpha$, IL-6 does not promote major inflammatory mediators [108], and is thus known as a pleiotropic cytokine. Additionally, IL-6 initiates many anti-inflammatory hepatocyte-derived acute-phase proteins and inhibits the expression of IL-1 and TNF $\alpha$ and induces IL-1ra and IL-10 after exercise [109].

Although IL-6 has both pro-inflammatory and anti-inflammatory effects, these effects are mediated by two different signaling pathways: classic-signaling and trans-signaling. Whereas classic-signaling involves IL-6 binding to the membrane-bound non-signaling $\alpha$-receptor IL-6R, leading to dimerization and activation of gp130, trans-signaling involves IL-6 binding to a soluble form of IL-6R (sIL-6R) that eventually forms a complex to activate gp130 [110]. This distinction is important, as cells that do not express membrane-bound IL-6R can still be activated by the IL-6/sIL-6R complex. In addition, 
trans-signaling allows lymphocyte trafficking into an inflamed area by controlling chemokine expression, promoting T-cell proliferation during colon cancer development, and regulating expression of adhesion molecules on endothelial cells [111]. Unlike classic-signaling, which is important for controlling homeostatic processes and immunological outcomes [112], trans-signaling is important for the recruitment and apoptosis of leukocytes, maintaining the effector function of $\mathrm{T}$ cells, and the inflammatory activation of stromal tissues [113]. Murine sepsis models and animal experiments have demonstrated the pro-inflammatory effects of IL-6 are dependent on trans-signaling whereas the anti-inflammatory effects of IL-6 depended on classic-signaling [114,115]. For atherosclerosis, mice models and human macrophage experiments demonstrated a lifetime IL- 6 deficiency enhances atherosclerotic plaque formation in ApoEK ${ }^{-/-}-\mathrm{IL}-6^{-/-}$mice, leading to worse vascular development processes [116], and that IL-6 enhanced the capacity of macrophages to ingest apoptotic cells and attenuated the pro-inflammatory phenotype of cholesterol-loaded macrophages [117]. Multiple reviews and studies demonstrated blocking IL-6 trans-signaling through the circulating soluble glycoprotein 130 (sgp130) prevented high-fat diet-induced macrophage recruitment into adipose tissue, and inhibited mononuclear cell-dominated inflammatory processes [118,119]. Sgp130 treatment has also been shown to decrease endothelial activation and intimal SMC infiltration, and reduce monocyte recruitment and atherosclerotic progression in hypercholesterolemic $\mathrm{Ldlr}^{-/-}$mice [120]. Treatments that target site IIb of the IL-6 receptor has also been shown to selectively block trans-signaling [121]. However, the association of sgp130 levels and CVD appears less straightforward in human studies, with many reporting an inverse, null, or positive association [122]. These differences could be attributed to the notion that higher sgp130 levels reflect higher fragility rather than a cause of adverse outcome of the subjects [123]. Nevertheless, promoting the classic-signaling pathway and inhibiting the trans-signaling pathway of IL-6 may have a protective effect for atherosclerotic patients.

Due to the potential atheroprotective effects of IL-6, many studies have attempted to establish a relationship between exercise and IL-6 levels. Findings from multiple reviews and human exercise experiments have demonstrated IL-6 significantly increases after 30 min and peaks at the end of $2.5 \mathrm{~h}$ of treadmill running [124-127]. These levels can increase up to 100-fold in an exponential manner after a 3-3.5 h marathon $[128,129]$. However, IL-6 levels rapidly decline, with a half-life of one to two hours. Additionally, IL-6 levels seem to correlate positively with exercise intensity. In fact, in a recent study involving ten healthy and active participants, those with high-intensity cycling training $(5 \times 4 \mathrm{~min}$ intervals at $80 \% \mathrm{VO}_{2 \max }$ interspersed with 3 min intervals at $50 \% \mathrm{VO}_{2 \max }$ ) had a 2.7-fold increase in IL-6 while those with low-intensity training ( 35 min cycling at $50 \% \mathrm{VO}_{2 \max }$ ) only had a 1.4-fold increase in IL-6 [130]. Scarce data is available regarding the relationship between different modes of exercise and IL-6 levels. However, a systematic review suggested, in an analysis of 67 exercise trials, while the mode of exercise does not appear to have an effect on IL-6 levels, protocols using running as the source of exercise seem to have the greatest increase in IL-6 [131]. Although more investigation is required to validate these results, these findings suggest longer periods of high-intensity running may lead to higher IL-6 levels and more anti-inflammatory benefits for atherosclerotic patients.

\subsection{IL-1ra}

IL-1 $\beta$ is widely recognized as a pro-inflammatory cytokine for atherosclerosis, as its systemic increase subsequently transforms the disease caused by a simple accumulation of lipids into a disorder with complex inflammatory events in the arterial wall [132]. With 12 antiparallel beta-strands arranged into a beta-trefoil, it is involved in a wide range of inflammatory processes in atherosclerosis, including structural and functional alterations on cardiac myocytes, regulation of MAP kinase and iNO pathways, induction of adrenomedullin and VEGF, vessel wall inflammation, leukocyte chemotaxis and adhesion, monocyte infiltration into the subendothelial space, and upregulation of matrix metalloproteinases to promote plaque instability [132]. To abolish these inflammatory effects, the most widely investigated inhibitor of IL-1 $\beta$ is the IL-1 receptor antagonist (IL-1ra). Although it has both soluble and intracellular isoforms, the soluble form binds to the IL-1 receptor to facilitate its anti-inflammatory activity and 
the intracellular form has been shown to interact with the third component of the COP9 signalosome CSN3 and inhibit the activity of CSN-associated kinases as well as IL-1-mediated release of IL-6 and IL-8 $[133,134]$. In multiple reviews and animal studies, administering IL-1ra or antibodies that target IL-1 $\beta$ has been shown to inhibit many atherogenic cytokines from endothelial cells and SMCs, such as IL-6, IL-8, IL-4, IL-7, MCP-1, and TNF $\alpha$, regulate matrix metalloproteinases of the extracellular matrix, such as MMP-13, inhibit vascular SMC proliferation, decrease foam-cell lesion size, improve outcomes in acute $\mathrm{MI}$ and ischemic stroke, and modulate plaque composition in $\mathrm{ApoE}^{-/-}$mice [135-141]. IL-1ra ${ }^{-/-}$mice also appear to be enriched in macrophages, depleted in SMCs, and develop fattier livers and hypercholesteroremia [134,142]. Additionally, endothelial cells lacking IL-1ra have been shown to have a reduced lifespan and growth compared to controls [134].

Many studies have attempted to establish a relationship between exercise and IL-1ra levels. IL-1ra levels appear to markedly increase after a marathon race, and repeated bouts of prolonged cycling at $75 \% \mathrm{VO}_{2 \max }$ levels provoked more pronounced increases in plasma IL-1ra levels in elite athletes $[143,144]$. IL-1ra levels increase further two hours after a marathon session, demonstrating they peak 1.5 to $2 \mathrm{~h}$ after exercise [124-126]. Resistance training has also been shown to increase IL-1ra levels, with only the highest intensity (10 to 12 repetitions at $80 \%$ of $1 \mathrm{RM}$ ) corresponding to a significant increase in IL-1ra levels [145-147]. Although these studies are limited by their small statistical power, these results suggest that repeated bouts of high-intensity endurance or resistance exercise could have more therapeutic potential for treating atherosclerosis.

\section{Efficacies of Existing Anti-Inflammatory Therapeutics in the Treatment of Atherosclerosis}

Unlike physical exercise, many current anti-inflammatory therapeutics at most only delay the progression of atherosclerosis, may be used by only a certain group of the general population, and are still under development and evaluation, despite their long-standing recognition in the treatment of atherosclerosis. Because they have been approved for other conditions that have similar features to atherosclerosis, they could be used to treat atherosclerosis, and their therapeutic efficacies and adverse effects have been extensively reviewed elsewhere [8,148-152]. These therapeutics can be broadly divided into four categories: "classic" anti-inflammatory drugs, biological pathway therapies, lipid mediators, and intracellular pathway inhibitors. To provide further context for the therapeutic potential of anti-inflammatory exerkines in the treatment of atherosclerosis, we discuss a few examples of anti-inflammatory therapeutics in each category, and briefly summarize their limited efficacies and current development. Table 1 offers a more extensive overview of these therapeutics, and describes their limited efficacies and highest stage of clinical development.

\section{1. "Classic" Anti-Inflammatory Drugs}

For the past few decades, many conventional anti-inflammatory drugs have been evaluated to treat atherosclerosis. For instance, methotrexate, a folic acid antagonist, downregulates adhesion molecules, inhibits cyclooxygenases and lipoxygenases, and modulates the secretion of cytokines and matrix metalloproteinases [153]. Many meta-analyses have suggested methotrexate is associated with a reduction in CVD mortality and myocardial infarction (MI) in patients with rheumatoid arthritis (RA) and psoriasis [154,155]; however, the METIS trial demonstrated no reductions in CRP levels or adverse CVD events among patients with ischemic heart failure (despite showing an improvement in functional class (New York Heart Association)) [156]. The CIRT trial, a phase 3 clinical trial, is currently underway to confirm these results in patients with stable coronary artery disease (CAD) [157]. As another example, colchicine is used in the treatment of arthritis and gout, and has a crucial role in atherosclerosis, as it can inhibit crystal-induced activation from macrophages, which can decrease the secretion of IL-1 $\beta[41,158]$. Many retrospective studies have suggested that colchicine treatment was associated with a decreased risk of MI $[159,160]$. Despite its poor design, the LoDoCo trial demonstrated colchicine was associated with a reduction of acute coronary syndrome (ACS), out-of-hospital cardiac arrest (OHCA), and non-cardioembolic ischemic stroke [161]. An alternative approach to inhibit inflammasome-dependent activation is to neutralize IL-1 $\beta$; this is currently being evaluated by the CANTOS trial [162]. 
Table 1. Current Anti-Inflammatory Therapeutics for Atherosclerosis.

\begin{tabular}{|c|c|c|c|}
\hline Type of Therapeutic & Categories and Examples & Efficacy & $\begin{array}{l}\text { Highest Stage } \\
\text { of Clinical } \\
\text { Development }\end{array}$ \\
\hline \multirow{3}{*}{$\begin{array}{l}\text { “Classic" anti- } \\
\text { inflammatory drugs }\end{array}$} & Methotrexate & $\begin{array}{l}\text { Reduces CVD mortality and MI in patients with RA and psoriasis }[154,155] \text {; does not reduce } \\
\text { CRP levels or adverse CVD events among patients with ischemic heart failure (METIS) [156] }\end{array}$ & Phase III \\
\hline & Colchicine & $\begin{array}{l}\text { Can inhibit crystal-induced activation from macrophages, which can decrease the secretion of } \\
\text { IL-1 } \beta[41,158] \text {; decreases MI risk }[159,160] \text {; reduces ACS, OHCA, and non-cardioembolic } \\
\text { ischemic stroke (LoDoCo) [161] }\end{array}$ & Phase III \\
\hline & Allopurinol & $\begin{array}{l}\text { Improves endothelial function and reduces levels of oxidative stress, and could reduce } \\
\text { atherosclerotic lesion size in ApoE knockout mice [163-165]; increases exercise tolerance, reduces } \\
\text { vascular tissue oxidative stress, improves endothelial function, and lowers mortality among } \\
\text { patients with CAD or heart failure [166] }\end{array}$ & Phase II \\
\hline \multirow{4}{*}{$\begin{array}{l}\text { Biological pathway } \\
\text { therapies }\end{array}$} & $\begin{array}{l}\text { TNF-inhibitors (etanercept, } \\
\text { infliximab, and adalimumab) }\end{array}$ & $\begin{array}{l}\text { Lowers risk of having CVD, CRP, and IL-6 levels and increases HDL levels in patients with } \\
\text { RA }[167,168] \text {; scarce data for atherosclerosis }\end{array}$ & Phase III \\
\hline & IL-1 inhibitors (canakinumab) & $\begin{array}{l}\text { Decreases CRP and IL-6 levels for patients with non-ST elevation ACS (NSTE-ACS) (MRC-ILA } \\
\text { Heart Study) [169], and reduces CRP, fibrinogen, and IL-6 levels in patients with Type } 2 \text { diabetes } \\
\text { and high CVD risk without major changes in LDL or HDL levels [170] }\end{array}$ & Phase III \\
\hline & $\begin{array}{l}\text { Anti-IL-12-subunit } \mathrm{p} 40 \\
\text { inhibitors (ustekinumab and } \\
\text { briakinumab) }\end{array}$ & $\begin{array}{l}\text { Similar odds ratio for CVD in patients treated with ustekinumab or briakinumab compared to } \\
\text { placebo, but a higher odds ratio for CVD for patients who received both treatments [171] }\end{array}$ & Phase III \\
\hline & Chemokine signaling therapy & $\begin{array}{l}\text { MLN1202, a MCP-1 inhibitor, significantly decreases CRP levels in participants with two or more } \\
\text { risk factors for atherosclerosis [172]; a CCL17-blocking antibody was developed that can limit } \\
\text { the expansion of regulatory T-cells, but no clinical data is available [173] }\end{array}$ & Phase II \\
\hline Lipid mediators & $\begin{array}{l}\text { sPLA }_{2} \text { inhibitors (most } \\
\text { advanced is varespladib) }\end{array}$ & $\begin{array}{l}\text { Significantly reduces the level of atherosclerotic lesions when given alone or with a statin in mice } \\
\text { studies [174,175]; significantly reduces LDL, CRP, and sPLA2-IIA levels and the number of } \\
\text { atherosclerotic lesions with atorvastatin (ACS-FRANCIS) [176]; associated with an increased risk } \\
\text { of MI and composite secondary end point of CVD mortality, MI, and stroke (VISTA-16) [177]; } \\
\text { certain sPLA2 isoforms may have different atherosclerotic properties in mice studies and thus } \\
\text { lead to varying atherosclerotic lesion sizes [178] }\end{array}$ & Phase III \\
\hline
\end{tabular}


Table 1. Cont.

\begin{tabular}{|c|c|c|c|}
\hline Type of Therapeutic & Categories and Examples & Efficacy & $\begin{array}{l}\text { Highest Stage } \\
\text { of Clinical } \\
\text { Development }\end{array}$ \\
\hline & $\begin{array}{l}\text { LpPLA }_{2} \text { inhibitors (most } \\
\text { advanced is darapladib) }\end{array}$ & $\begin{array}{l}\text { Reduces LpPLA2 activity in plasma and arteries, decreases plaque area in the left anterior } \\
\text { descending coronary artery, and reduces the necrotic core area [179]; reduces necrotic core } \\
\text { growth but not coronary plaque volume (IBIS-2) [180]; no beneficial effects in preventing the } \\
\text { primary endpoint of CVD, MI, or stroke in 15,828 patients with CAD (STABILITY) [181]; no } \\
\text { reduction in the risk of major coronary events in 13,026 patients with ACS (SOLID-TIMI 52) [182] }\end{array}$ & Phase III \\
\hline & NSAIDs & $\begin{array}{l}\text { COX-1: aspirin could lead to irreversible inhibition of COX-1 in platelets [183]; high doses of } \\
\text { aspirin could inhibit COX-2 and prevent inflammation-mediated endothelial dysfunction and } \\
\text { release IL-7 effects while lead to more GI side effects [184]; terutroban was not superior to aspirin } \\
\text { and could lead to minor bleeding in a follow-up of } 3.5 \text { years in }>19,000 \text { patients with previous } \\
\text { ischemic stroke or transient ischemic attack (PERFORM) [185] } \\
\text { COX-2: associated with increased CVD risk that led to their withdrawal [97,98]; celecoxib } \\
\text { demonstrated an insignificant number of fewer CVD events compared to ibuprofen and } \\
\text { naproxen (PRECISION) [186]; significantly increased risk of OHCA among patients who used } \\
\text { ibuprofen and diclofenac but not those who consumed naproxen, celecoxib, or rofecoxib [187] }\end{array}$ & $\begin{array}{l}\text { Marketed } \\
\text { (for aspirin) }\end{array}$ \\
\hline & Anti-leukotrienes & $\begin{array}{l}\text { Inhibits FLAP in ApoE and Ldlr double-knockout mice [188]; reduces atherosclerosis and } \\
\text { blocking leukotriene receptors have beneficial effects [188]; nonsignificant reduction in CRP for } \\
\text { patients at risk for CAD treated with DG-031 (veliflapon) [189]; significantly reduced plaque } \\
\text { volume just after } 24 \text { weeks for ACS patients who received the 5-LO inhibitor atreleuton } \\
\text { treatment [190] }\end{array}$ & Phase III \\
\hline & Statins & $\begin{array}{l}\text { Decreases cholesterol synthesis by inhibiting the 3-hydroxy-3-methylglutaryl-coenzyme A } \\
\text { (HMG CoA) reductase enzyme [36]; for pravastatin, post-MI patients who received the treatment } \\
\text { had decreased CRP levels (but not cholesterol) (CARE) [191] while men with moderate } \\
\text { hypercholesterolemia with no history of MI had significantly reduced MI incidence and death } \\
\text { from CVD causes without affecting the risk of death from non-CVD factors (WOSCOP) [192]; } \\
\text { for lovastatin, patients without a history of CVD had a significant reduction in serious CVD } \\
\text { events in and only patients with LDL levels }<150 \text { mg per dL and CRP levels }>2 \text { mg per liter had } \\
\text { significant clinical benefit (AFCAPS/TexCAPS ) [193]; for simvastatin patients with angina } \\
\text { pectoris or previous MI had improved survival (4S) [194]; for atorvastatin, patients who received } \\
\text { the treatment had a significant reduction in CRP and LDL levels than those who received the } \\
\text { pravastatin treatment (PROVE IT-TIMI-22) [195]; for rosuvastatin, } 40 \text { mg/day doses resulted in } \\
\text { significant regression of atherosclerosis among 507 patients with intravascular ultrasound trials } \\
\text { (ASTEROID) [196], maximal doses of rosuvastatin and atorvastatin resulted in significant } \\
\text { regression of coronary atherosclerosis (SATURN) [197], and lowering LDL levels with statins } \\
\text { would reduce adverse CVD events in patients with } \leq 130 \text { mg per dl LDL levels (JUPITER) [198] }\end{array}$ & Marketed \\
\hline
\end{tabular}


Table 1. Cont.

\begin{tabular}{|c|c|c|c|}
\hline Type of Therapeutic & Categories and Examples & Efficacy & $\begin{array}{l}\text { Highest Stage } \\
\text { of Clinical } \\
\text { Development }\end{array}$ \\
\hline & $\begin{array}{l}\text { Cholesterol absorption } \\
\text { inhibitors (ezetimibe) }\end{array}$ & $\begin{array}{l}\text { Reduces LDL by } 15-22 \% \text { alone and } 15-20 \% \text { when combined with a statin; clinical trials support } \\
\text { its administration as second-line therapy in statin-intolerant patients or in patients with } \\
\text { contraindication to statins (PRECISE-IVUS; IMPROVE IT) }[199,200]\end{array}$ & Phase III \\
\hline & $\begin{array}{l}\text { Bile acid sequestrants } \\
\text { (cholestyramine, colestipol, } \\
\text { and colesvelam) }\end{array}$ & $\begin{array}{l}\text { Reduce LDL levels of } 18-25 \% \text { at the highest dose [201]; cholestyramine and colestipol } \\
\text { have been found to have GI adverse effects and major interactions with other drugs, } \\
\text { which limit their use [59] }\end{array}$ & Phase III \\
\hline & $\begin{array}{l}\text { Proprotein convertase } \\
\text { subtilisin/ kexin type-9 } \\
\text { (PCSK-9) inhibitors }\end{array}$ & $\begin{array}{l}\text { Lower LDL levels more than ezetimibe combined with statins as they can prevent PCSK-9 from } \\
\text { binding to LDL receptors in the liver and stimulating LDL absorption and degradation of these } \\
\text { receptors [59]; clinical trials have demonstrated that evolocumab and alirocumab could decrease } \\
\text { atheroma volume and CVD events [202-204]; PCSK-9 inhibitors are still limited by their } \\
\text { relatively high costs [59] }\end{array}$ & Phase III \\
\hline & Fibrates & $\begin{array}{l}\text { Lower triglycerides and triglyceride-rich lipoprotein particles up to more than } 50 \% \text { while } \\
\text { increasing HDL levels [59]; clinical trials and meta-analyses failed to demonstrate good CVD } \\
\text { outcomes [205] }\end{array}$ & Phase III \\
\hline & $\begin{array}{l}\text { n-3 fatty acids } \\
\text { (eicosapentaenoic acid and } \\
\text { docosahexaenoic acid) }\end{array}$ & $\begin{array}{l}\text { Lower triglyceride levels up to } 45 \% \text { [206]; no significant effect of } \omega-3 \text { fatty acids on composite } \\
\text { CVD events [207] }\end{array}$ & Phase III \\
\hline & Niacin & $\begin{array}{l}\text { Could reduce CVD events and adverse coronary endpoints; clinical trials have demonstrated } \\
\text { niacin did not lead to a reduction in CVD events and may even cause severe side effects } \\
\text { (AIM-HIGH; ACCORD; HPS2-THRIVE) [34] }\end{array}$ & Phase III \\
\hline & $\begin{array}{l}\text { Cholesteryl ester transfer } \\
\text { protein (CETP) inhibitors }\end{array}$ & $\begin{array}{l}\text { Could reduce LDL levels and increase HDL levels, but clinical trials have failed to determine } \\
\text { their efficacies (ILLUMINATE; Dal-OUTCOMES; ACCELERATE); only anacetrapib is still } \\
\text { actively investigated, as it could decrease LDL levels [208] }\end{array}$ & Phase III \\
\hline \multirow{2}{*}{$\begin{array}{l}\text { Intracellular pathway } \\
\text { inhibitors }\end{array}$} & p38 MAPK inhibitors & $\begin{array}{l}\text { p38 inhibitor SB203580 treatment had attenuated atherosclerosis [209]; dilmapimod could lead to } \\
\text { lower levels of CRP [210]; losmapimod could improve endothelial function just after four weeks } \\
\text { or decrease CRP levels in patients with hypercholesterolemia or had a history of atherosclerosis } \\
\text { (SOLSTICE) [211-214] }\end{array}$ & Phase II \\
\hline & NADPH oxidase inhibitors & $\begin{array}{l}\text { Nox1 or Nox2 deletion in ApoE knockout mice reduces atherosclerotic lesion size and correlates } \\
\text { with lower levels of aortic superoxide [215,216]; the Nox1/Nox4 inhibitors GKT136901 and } \\
\text { GKT137831 do not completely suppress ROS production but could slow or prevent disease } \\
\text { progression [217] }\end{array}$ & Phase II \\
\hline
\end{tabular}


Table 1. Cont.

\begin{tabular}{|c|c|c|c|}
\hline Type of Therapeutic & Categories and Examples & Efficacy & $\begin{array}{l}\text { Highest Stage } \\
\text { of Clinical } \\
\text { Development }\end{array}$ \\
\hline & $\begin{array}{l}\text { PDE (PDE3, PDE4, PDE5) } \\
\text { inhibitors }\end{array}$ & $\begin{array}{l}\text { PDE3 inhibitors: Cilostazol decreases atherosclerotic lesion size, reduces macrophage } \\
\text { accumulation [218], and inhibits vascular SMC proliferation in vitro [148] and intimal } \\
\text { hyperplasia in vivo [219]; reduces restenosis [122] } \\
\text { PDE4 inhibitors: Roflumilast decreases cytokine and adhesion molecule expression [220]; } \\
\text { decreases the rate of CVD in chronic obstructive pulmonary disease (COPD) patients [221] } \\
\text { PDE5 inhibitors (sildenafil, vardenafil, and tadalafil): sildenafil could restore endothelial } \\
\text { function and slow atherosclerosis development in ApoE knockout mice [222] }\end{array}$ & Phase IV \\
\hline & $\begin{array}{l}\text { Antioxidants (most advanced } \\
\text { therapeutic is succinobucol) }\end{array}$ & $\begin{array}{l}\text { Decreases diabetic occurrences and composite secondary end points (these include CVD death, } \\
\text { cardiac arrest, MI, and stroke) in patients who had MI or unstable angina (ARISE) [223]; } \\
\text { improves effects on lumen dimensions in stented vessels and leads to a significant reduction in } \\
\text { plasma myeloperoxidase levels (CART-2) [224] }\end{array}$ & Phase III \\
\hline
\end{tabular}




\subsection{Biological Pathway Therapies}

Recombinant proteins and monoclonal antibodies of cytokines have also been used to treat CVDs and other chronic inflammatory diseases. TNF inhibitors, such as etanercept, infliximab, and adalimumab, are commonly used in patients with RA, psoriasis, or other autoimmune diseases, as they have a considerably increased CVD risk. Geborek et al. and Barerra et al. demonstrated RA patients who received the anti-TNF therapy had a 0.46 rate of having a CVD event than those who did not, and had increased HDL levels and decreased CRP and IL-6 levels [167,168]. However, there is scarce clinical trial data on the efficacy of anti-TNF inhibitors. Another potential biological pathway therapy is IL-1 inhibitors, as in endothelial cells, IL-1 modulates hemostatic properties and leukocyte adhesion while it induces SMCs to produce prostanoids and IL-6 [225]. The MRC-ILA Heart Study demonstrated a significant decrease in CRP and IL-6 levels for patients with non-ST elevation ACS (NSTE-ACS) who had the IL-1 receptor antagonist treatment [169]. In a separate clinical trial that randomly allocated canakinumab, a human monoclonal antibody that neutralizes IL-1 $\beta$, to 556 men and women with Type 2 diabetes and high CVD risk, those who received the treatment had a significant reduction in CRP, fibrinogen, and IL-6 levels without major changes in LDL or HDL levels [170].

\subsection{Lipid Mediators}

Lipid mediators, such as phospholipase A2 inhibitors (secretory PLA2 (sPLA2) inhibitors, lipoprotein-associated PLA2 (LpPLA2) inhibitors, nonsteroidal anti-inflammatory drugs (NSAIDs)), antileukotrienes, statins, and other LDL, triglyceride, and HDL lowering therapies, either inhibit lipid biosynthesis or various seven-transmembrane G-protein coupled receptors. An example of NSAIDs is COX-2 inhibitors, and they have favorable effects on inflammation, oxidative stress, endothelial function, and tissue factor expression, but are associated with increased CVD risk [97,98]. Celecoxib, a COX-2 inhibitor, has been associated with fewer CVD events compared to ibuprofen and naproxen in the PRECISION trial; however, this result was not significant [186]. Additionally, a recent study using a nationwide cohort of 28,947 patients with OHCA of whom 3376 patients were treated with an NSAID also found a significantly increased risk of OHCA among patients who used ibuprofen and diclofenac but not those who consumed naproxen, celecoxib, or rofecoxib [187]. Another lipid mediator is anti-leukotrienes, as arachidonic acid metabolism by arachidonate 5-lipoxygenase (5-LO) and 5-LO-activating protein (FLAP) generates leukotrienes that have atherosclerotic implications, including lesion development, induction and activation of leukocytes, SMC proliferation, and endothelial dysfunction [226]. Inhibiting 5-LO-activating protein (FLAP) in ApoE and Ldlr double-knockout mice could reduce atherosclerosis and blocking leukotriene receptors have beneficial effects [188]. Clinical trials have demonstrated a non-significant reduction in CRP in patients at risk for CAD treated with DG-031 (veliflapon) [189] and significantly reduced plaque volume in patients with ACS treated with the 5-LO inhibitor atreleuton just after 24 weeks [190]. Statins are another popular atherosclerotic therapeutic, as they could decrease cholesterol synthesis by inhibiting the 3-hydroxy-3-methylglutaryl-coenzyme A (HMG CoA) reductase enzyme that blocks mevalonate synthesis [36]. For pravastatin, the CARE study demonstrated post-MI patients who received the treatment had decreased CRP levels (but not cholesterol) [191] while the WOSCOP trial demonstrated it significantly reduced MI incidence and death from CVD causes without affecting the risk of death from non-CVD factors in men with moderate hypercholesterolemia with no history of MI [192]. For lovastatin, the AFCAPS/TexCAPS trial showed a significant reduction in serious CVD events in patients without a history of CVD while only patients with LDL levels $<150 \mathrm{mg}$ per $\mathrm{dl}$ and CRP levels $>2 \mathrm{mg}$ per liter had significant clinical benefit [193]. The $4 \mathrm{~S}$ trial also demonstrated treatment with simvastatin improves survival among 4444 patients with angina pectoris or previous MI [194]. For atorvastatin, the PROVE IT-TIMI 22 trial demonstrated patients who received the treatment had a significant reduction in CRP and LDL levels than those who received the pravastatin treatment [195]. For rosuvastatin, the ASTEROID trial discovered very high-intensity statin therapy using $40 \mathrm{mg} /$ day of rosuvastatin resulted in significant regression of atherosclerosis among 507 patients with intravascular 
ultrasound trials [196], the SATURN trial found that maximal doses of rosuvastatin and atorvastatin resulted in significant regression of coronary atherosclerosis [197], and the JUPITER trial demonstrated lowering LDL levels with statins would reduce adverse CVD events in patients with $\leq 130 \mathrm{mg}$ per $\mathrm{dL}$ LDL levels [198]. LDL and triglyceride lowering therapies also gain considerable interest. For instance, fibrates, which are agonists of peroxisome proliferator-activated receptor $\alpha$ (PPAR- $\alpha$ ), can lower triglycerides and triglyceride-rich lipoprotein particles up to more than 50\% while increasing HDL levels [59]. However, results from several clinical trials and meta-analyses failed to demonstrate good CVD outcomes [201].

\subsection{Intracellular Pathway Inhibitors}

The final type of anti-inflammatory therapeutic for atherosclerosis are intracellular pathway inhibitors, which modulate intracellular inflammatory responses and include p38 mitogen-activated protein kinase (MAPK) inhibitors, statins, NADPH oxidase inhibitors, and phosphodiesterase (PDE) inhibitors. PDE inhibitors, such as PDE3, PDE4, and PDE5 inhibitors, are of interest because blocking phosphodiesterases, which degrade anti-inflammatory cyclic nucleotides, might enhance the effects of endogenous anti-inflammatory mediators. For example, cilostazol, a PDE3 inhibitor, has been shown to decrease atherosclerotic lesion size, reduce macrophage accumulation in ApoE knockout mice [218], and inhibit vascular SMC proliferation in vitro [148] and intimal hyperplasia in vivo [219]. In addition, clinical trial data suggest that cilostazol reduces restenosis [147]. Another potential intracellular pathway inhibitor is antioxidants. Succinobucol (AGI-1067), which is related to probucol, is the most promising therapy in this category [8]. Results from the ARISE clinical trial suggested that, among a group of 6144 patients who had MI or unstable angina within a year before recruitment, those who received succinobucol had a decrease in diabetic occurrences and fewer patients had fewer composite secondary end points (these include CVD death, cardiac arrest, MI, and stroke) [223]. In the CART-2 trial, succinobucol treatment had favorable effects on lumen dimensions in stented vessels and led to a significant reduction in plasma myeloperoxidase levels [224].

\section{Challenges and Future Directions}

Despite the anti-inflammatory benefits of exercise and exerkines, several challenges must be addressed before they are deployed in the clinic. One of the key challenges in exploiting the therapeutic potential of exerkines is to develop exerkine analogues that take into account their proteolytic instability, short half-lives, immunogenicity, and toxicity when administering them into patients. Recent reviews have suggested protein pharmaceuticals are viable options as currently there are two dominant technologies that have developed many drugs in the market or in clinical trials: PEGylation and Fc fusion [227,228]. As of 2016, there were 12 marketed PEGylated biopharmaceuticals [229]. Further work is needed in this area to determine other viable therapeutic options.

Another key challenge in exploiting the therapeutic potential of exerkines is to achieve tissue-specific targeting without having side effects. Although many exerkines are expressed in skeletal muscle or adipose tissue and are induced by muscle contraction, they are also expressed in other tissues and could generate side effects when they are being injected into a patient $[228,230]$. Recent findings have suggested that nanotechnology could be used to address this issue as nanoparticles can target specific tissues and can provide variable circulation times by controlling the target surface and size [231,232].

A final challenge in exerkine biology is to clarify the relationship between these anti-inflammatory exerkines with different types of exercise. As mentioned in earlier sections of this review, most of the studies to date have focused primarily on endurance exercise and while there are other anti-atherogenic exerkines, little data is available regarding their relationship with exercise. Additionally, due to the low statistical power of most available studies, many of the above findings need to be validated in larger populations while taking into account various health characteristics of these subjects. Although 
challenging, collectively, these findings will help elucidate the therapeutic potential of these exerkines in the treatment of atherosclerosis.

\section{Conclusions}

A growing body of evidence suggests that exercise and anti-inflammatory exerkines could have therapeutic potential in the treatment of atherosclerosis, as they have multisystemic, anti-inflammatory benefits. Unlike anti-inflammatory therapeutics, which at most only delay the progression of atherosclerotic disease and are still under evaluation, physical exercise increases energy expenditure, promotes longevity, and helps patients reduce the risk for many chronic diseases [9]. It also brings about many anti-inflammatory benefits, such as reducing visceral fat, decreasing pro-inflammatory monocytes and regulatory T-cells in the circulation, and inhibiting monocyte and macrophage infiltration into adipose tissue. Several exerkines are also potentially useful to treat atherosclerosis, as they have many benefits, including inhibiting monocyte adhesion and promoting endothelial cell survival potential. Current exerkine targets for atherosclerosis should include irisin, adiponectin, IL-6, and IL-1ra, among others, as they have the most promising results. While further studies are necessary to fully understand the relationship between these anti-inflammatory exerkines and exercise and develop viable therapeutic analogues for atherosclerotic patients, physical exercise and bioengineered exerkines should serve as potential therapeutic targets for the treatment of atherosclerosis in the future.

Acknowledgments: This work is not supported by any funding agencies.

Author Contributions: Megan Yu wrote and revised the paper. Sheng-Feng Tsai and Yu-Min Kuo approved the final version.

Conflicts of Interest: The authors declare no conflict of interest.

\section{References}

1. WHO. World Health Statistics 2016: Monitoring Health for the SDGs Sustainable Development Goals; World Health Organization: Geneva, Switzerland, 2016.

2. American Heart Association. Heart Disease, Stroke and Research Statistics At-a-Glance. Available online: https://www.heart.org/idc/groups/ahamah-public/@wcm/@sop/@smd/documents/downloadable/ ucm_491265.pdf (accessed on 10 June 2017).

3. Lusis, A.J. Atherosclerosis. Nature 2000, 407, 233-241. [CrossRef] [PubMed]

4. Bentzon, J.F.; Otsuka, F.; Virmani, R.; Falk, E. Mechanisms of plaque formation and rupture. Circ. Res. 2014, 114, 1852-1866. [CrossRef] [PubMed]

5. Berliner, J.A.; Navab, M.; Fogelman, A.M.; Frank, J.S.; Demer, L.L.; Edwards, P.A.; Watson, A.D.; Lusis, A.J. Atherosclerosis: Basic mechanisms. Oxidation, inflammation, and genetics. Circulation 1995, 91, 2488-2496. [CrossRef] [PubMed]

6. Kwak, B.R.; Back, M.; Bochaton-Piallat, M.L.; Caligiuri, G.; Daemen, M.J.; Davies, P.F.; Hoefer, I.E.; Holvoet, P.; Jo, H.; Krams, R.; et al. Biomechanical factors in atherosclerosis: Mechanisms and clinical implications. Eur. Heart J. 2014, 35, 3013-3020. [CrossRef] [PubMed]

7. Ross, R. Atherosclerosis-An inflammatory disease. N. Engl. J. Med. 1999, 340, 115-126. [CrossRef]

8. Charo, I.F.; Taub, R. Anti-inflammatory therapeutics for the treatment of atherosclerosis. Nat. Rev. Drug Discov. 2011, 10, 365-376. [CrossRef] [PubMed]

9. Pedersen, B.K.; Febbraio, M.A. Muscles, exercise and obesity: Skeletal muscle as a secretory organ. Nat. Rev. Endocrinol. 2012, 8, 457-465. [CrossRef] [PubMed]

10. Safdar, A.; Saleem, A.; Tarnopolsky, M.A. The potential of endurance exercise-derived exosomes to treat metabolic diseases. Nat. Rev. Endocrinol. 2016, 12, 504-517. [CrossRef] [PubMed]

11. Kovacic, S.; Bakran, M. Genetic susceptibility to atherosclerosis. Stroke Res. Treat. 2012, $2012,362941$. [CrossRef] [PubMed]

12. Cheng, C.; Tempel, D.; van Haperen, R.; van der Baan, A.; Grosveld, F.; Daemen, M.J.; Krams, R.; de Crom, R. Atherosclerotic lesion size and vulnerability are determined by patterns of fluid shear stress. Circulation 2006, 113, 2744-2753. [CrossRef] [PubMed] 
13. Tabas, I.; García-Cardeña, G.; Owens, G.K. Recent insights into the cellular biology of atherosclerosis. J. Cell Biol. 2015, 209, 13-22. [CrossRef] [PubMed]

14. Murphy, P.A.; Hynes, R.O. Alternative splicing of endothelial fibronectin is induced by disturbed hemodynamics and protects against hemorrhage of the vessel wall. Arterioscler. Thromb. Vasc. Biol. 2014, 34, 2042-2050. [CrossRef] [PubMed]

15. Liu, Y.; Collins, C.; Kiosses, W.B.; Murray, A.M.; Joshi, M.; Shepherd, T.R.; Fuentes, E.J.; Tzima, E. A novel pathway spatiotemporally activates Rac1 and redox signaling in response to fluid shear stress. J. Cell Biol. 2013, 201, 863-873. [CrossRef] [PubMed]

16. Jung, B.; Obinata, H.; Galvani, S.; Mendelson, K.; Ding, B.S.; Skoura, A.; Kinzel, B.; Brinkmann, V.; Rafii, S.; Evans, T.; et al. Flow-regulated endothelial S1P receptor-1 signaling sustains vascular development. Dev. Cell 2012, 23, 600-610. [CrossRef] [PubMed]

17. Li, J.; Hou, B.; Tumova, S.; Muraki, K.; Bruns, A.; Ludlow, M.J.; Sedo, A.; Hyman, A.J.; McKeown, L.; Young, R.S.; et al. Piezo1 integration of vascular architecture with physiological force. Nature 2014, 13, 279-282. [CrossRef] [PubMed]

18. Baeyens, N.; Mulligan-Kehoe, M.J.; Corti, F.; Simon, D.D.; Ross, T.D.; Rhodes, J.M.; Wang, T.Z.; Mejean, C.O.; Simons, M.; Humphrey, J.; et al. Syndecan 4 is required for endothelial alignment in flow and atheroprotective signaling. Proc. Natl. Sci. Acad. USA 2014, 111, 17308-17313. [CrossRef] [PubMed]

19. Grundy, S.M. Cholesterol and coronary heart disease. A new era. JAMA 1986, 256, 2849-2858. [CrossRef] [PubMed]

20. Avraham-Davidi, I.; Ely, Y.; Pham, V.N.; Castranova, D.; Grunspan, M.; Malkinson, G.; Gibbs-Bar, L.; Mayseless, O.; Allmog, G.; Lo, B.; et al. ApoB-containing lipoproteins regulate angiogenesis by modulating expression of vegf receptor 1. Nat. Med. 2012, 18, 967-973. [CrossRef] [PubMed]

21. Kesherwani, V.; Chavali, V.; Hackfort, B.T.; Tyagi, S.C.; Mishra, P.K. Exercise ameliorates high fat diet induced cardiac dysfunction by increasing interleukin 10. Front. Physiol. 2015, 6, 124. [CrossRef] [PubMed]

22. Freeman, M.; Ashkenas, J.; Rees, D.J.; Kingsley, D.M.; Copeland, N.G.; Jenkins, N.A.; Krieger, M. An ancient, highly conserved family of cysteine-rich protein domains revealed by cloning type I and type II murine macrophage scavenger receptors. Proc. Natl. Acad. Sci. USA 1990, 87, 8810-8814. [CrossRef] [PubMed]

23. Sparrow, C.P.; Parthasarathy, S.; Steinberg, D. A macrophage receptor that recognizes oxidized low density lipoprotein but not acetylated low density lipoprotein. J. Biol. Chem. 1989, 264, 2599-2604. [PubMed]

24. Chi, Z.; Melendez, A.J. Role of cell adhesion molecules and immune-cell migration in the initiation, onset and development of atherosclerosis. Cell Adhes. Migr. 2007, 1, 171-175. [CrossRef]

25. Barter, P. The role of HDL-cholesterol in preventing atherosclerotic disease. Eur. Heart J. Suppl. 2005, 7 (suppl._F), F4-F8. [CrossRef]

26. Soran, H.; Schofield, J.D.; Durrington, P.N. Antioxidant properties of HDL. Front. Pharmacol. 2015, 6, 222. [CrossRef] [PubMed]

27. Annema, W.; von Eckardstein, A. Dysfunctional high-density lipoproteins in coronary heart disease: Implications for diagnostics and therapy. Transl. Res. 2016, 173, 30-57. [CrossRef] [PubMed]

28. Sorrentino, S.A.; Besler, C.; Rohrer, L.; Meyer, M.; Heinrich, K.; Bahlmann, F.H.; Mueller, M.; Horvath, T.; Doerries, C.; Heinemann, M.; et al. Endothelial-vasoprotective effects of high-density lipoprotein are impaired in patients with type 2 diabetes mellitus but are improved after extended-release niacin therapy. Circulation 2010, 121, 110-122. [CrossRef] [PubMed]

29. Besler, C.; Heinrich, K.; Rohrer, L.; Doerries, C.; Riwanto, M.; Shih, D.M.; Chroni, A.; Yonekawa, K.; Stein, S.; Schaefer, N.; et al. Mechanisms underlying adverse effects of HDL on enos-activating pathways in patients with coronary artery disease. J. Clin. Investig. 2011, 121, 2693-2708. [CrossRef] [PubMed]

30. Speer, T.; Rohrer, L.; Blyszczuk, P.; Shroff, R.; Kuschnerus, K.; Krankel, N.; Kania, G.; Zewinger, S.; Akhmedov, A.; Shi, Y.; et al. Abnormal high-density lipoprotein induces endothelial dysfunction via activation of toll-like receptor-2. Immunity 2013, 38, 754-768. [CrossRef] [PubMed]

31. Zewinger, S.; Speer, T.; Kleber, M.E.; Scharnagl, H.; Woitas, R.; Lepper, P.M.; Pfahler, K.; Seiler, S.; Heine, G.H.; Marz, W.; et al. HDL cholesterol is not associated with lower mortality in patients with kidney dysfunction. J. Am. Soc. Nephrol. 2014, 25, 1073-1082. [CrossRef] [PubMed]

32. Weichhart, T.; Kopecky, C.; Kubicek, M.; Haidinger, M.; Doller, D.; Katholnig, K.; Suarna, C.; Eller, P.; Tolle, M.; Gerner, C.; et al. Serum amyloid A in uremic HDL promotes inflammation. J. Am. Soc. Nephrol. 2012, 23, 934-947. [CrossRef] [PubMed] 
33. Silbernagel, G.; Schottker, B.; Appelbaum, S.; Scharnagl, H.; Kleber, M.E.; Grammer, T.B.; Ritsch, A.; Mons, U.; Holleczek, B.; Goliasch, G.; et al. High-density lipoprotein cholesterol, coronary artery disease, and CVD mortality. Eur. Heart J. 2013, 34, 3563-3571. [CrossRef] [PubMed]

34. Marz, W.; Kleber, M.E.; Scharnagl, H.; Speer, T.; Zewinger, S.; Ritsch, A.; Parhofer, K.G.; von Eckardstein, A.; Landmesser, U.; Laufs, U. HDL cholesterol: Reappraisal of its clinical relevance. Clin. Res. Cardiol. 2017. [CrossRef] [PubMed]

35. Schwartz, D.; Chaverri-Almada, L.; Berliner, J.A.; Kirchgessenr, T.; Quismorio, D.C.; Fang, Z.T.; Tekamp-Olson, P.; Lusis, A.J.; Fogelman, A.M.; Territo, M.C. The role of a grohomologue in monocyte adhesion to endothelium. J. Clin. Investig. 1994, 94, 1968-1973. [CrossRef] [PubMed]

36. Tacke, F.; Alvarez, D.; Kaplan, T.J.; Jakubzick, C.; Spanbroek, R.; Llodra, J.; Garin, A.; Liu, J.; Mack, M.; van Rooijen, N.; et al. Monocyte subsets differentially employ CCR2, CCR5, and CX3CR1 to accumulate within atherosclerotic plaques. J. Clin. Investig. 2007, 117, 185-194. [CrossRef] [PubMed]

37. Murphy, A.J.; Dragoljevic, D.; Tall, A.R. Cholesterol efflux pathways regulate myelopoiesis: A potential link to altered macrophage function in atherosclerosis. Front. Immunol. 2014, 5, 490. [CrossRef] [PubMed]

38. Ushing, S.D.; Berliner, J.A.; Valente, A.J.; Territo, M.C.; Navab, M.; Parhami, F.; Gerrity, R.; Schwartz, C.J.; Fogelman, A.M. Minimally modified LDL induces monocyte chemotactic protein 1 in human endothelial and smooth muscle cells. Proc. Natl. Acad. Sci. USA 1990, 87, 5134-5138. [CrossRef]

39. Rajavashisth, T.B.; Andalibi, A.; Territo, M.C.; Berliner, J.A.; Navab, M.; Fogelman, A.M.; Lusis, A.J. Induction of endothelial cell expression of granulocyte and macrophage colony-stimulating factors by modified low-density lipoproteins. Nature 1990, 344, 254-257. [CrossRef] [PubMed]

40. Lu, X.; Kakkar, V. Inflammasome and atherogenesis. Curr. Pharm. Des. 2014, 20, 108-124. [CrossRef] [PubMed]

41. Duewell, P.; Kono, H.; Rayner, K.J.; Sirois, C.M.; Vladimer, G.; Bauernfeind, F.G.; Abela, G.S.; Franchi, L.; Nuñez, G.; Schnurr, M.; et al. NLRP3 inflammasomes are required for atherogenesis and activated by cholesterol crystals. Nature 2010, 464, 1357-1361. [CrossRef] [PubMed]

42. Archer, S.L.; Huang, J.M.; Hampl, V.; Nelson, D.P.; Shultz, P.J.; Weir, E.K. Nitric oxide and cGMP cause vasorelaxation by activation of a charybdotoxin-sensitive $\mathrm{K}$ channel by cGMP-dependent protein kinase. Proc. Natl. Acad. Sci. USA 1994, 91, 7583-7587. [CrossRef] [PubMed]

43. Mutze, S.; Hebling, U.; Stremmel, W.; Wang, J.; Arnhold, J.; Pantopoulos, K.; Mueller, S. Myeloperoxidase-derived hypochlorous acid antagonizes the oxidative stress-mediated activation of iron regulatory protein 1. J. Biol. Chem. 2003, 278, 40542-40549. [CrossRef] [PubMed]

44. Oomi, K.; Posio, P.; Ala-Korpela, M.; Jauhiainen, M.; Kovanen, P.T. Sphingomyelinase Induces Aggregation and Fusion of Small Very Low-Density Lipoprotein and Intermediate-Density Lipoprotein Particles and Increases Their Retention to Human Arterial Proteoglycans. Arterioscler. Thromb. Vasc. Biol. 2005, 25, 1678-1683.

45. Collot-Teixeira, S.; Martin, J.; McDermott-Roe, C.; Poston, R.; McGregor, J.L. Cd36 and macrophages in atherosclerosis. Cardiovasc. Res. 2007, 75, 468-477. [CrossRef] [PubMed]

46. Kunnert, B.; Krug, H. The composition of cholesterol esters in fatty streaks and atherosclerotic plaques of the human aorta: Histochromatographic investigations. Atherosclerosis 1971, 13, 93-101. [CrossRef]

47. Rzucidlo, E.M.; Martin, K.A.; Powell, R.J. Regulation of vascular smooth muscle cell differentiation. J. Vasc. Surg. 2007, 45 (Suppl. A), A25-A32. [CrossRef] [PubMed]

48. Perisic Matic, L.; Rykaczewska, U.; Razuvaev, A.; Sabater-Lleal, M.; Lengquist, M.; Miller, C.L.; Ericsson, I.; Röhl, S.; Kronqvist, M.; Aldi, S.; et al. Phenotypic modulation of smooth muscle cells in atherosclerosis is associated with downregulation of LMOD1, SYNPO2, PDLIM7, PLN, and SYNM. Arterioscler. Thromb. Vasc. Biol. 2016, 36, 1947-1961. [CrossRef] [PubMed]

49. Alexander, M.R.; Owens, G.K. Epigenetic control of smooth muscle cell differentiation and phenotypic switching in vascular development and disease. Annu. Rev. Physiol. 2012, 74, 13-40. [CrossRef] [PubMed]

50. Bentzon, J.F.; Falk, E. Circulating smooth muscle progenitor cells in atherosclerosis and plaque rupture: Current perspective and methods of analysis. Vasc. Pharmacol. 2010, 52, 11-20. [CrossRef] [PubMed]

51. Stary, H.C. The development of calcium deposits in atherosclerotic lesions and their persistence after lipid regression. Am. J. Cardiol. 2001, 88, 16E-19E. [CrossRef] 
52. Lin, J.; Li, H.; Yang, M.; Ren, J.; Huang, Z.; Han, F.; Huang, J.; Ma, J.; Zhang, D.; Zhang, Z.; et al. A role of RIP3-mediated macrophage necrosis in atherosclerosis development. Cell Rep. 2013, 3, 200-210. [CrossRef] [PubMed]

53. Stary, H.C.; Chandler, A.B.; Dinsmore, R.E.; Fuster, V.; Glagov, S.; Insull, W., Jr.; Rosenfeld, M.E.; Schwartz, C.J.; Wagner, W.D.; Wissler, R.W. A definition of advanced types of atherosclerotic lesions and a histological classification of atherosclerosis. A report from the Committee on Vascular Lesions of the Council on Arteriosclerosis, American Heart Association. Circulation 1995, 92, 1355-1374. [CrossRef] [PubMed]

54. Falk, E. Why do plaques rupture? Circulation 1992, 86, III30-III42. [PubMed]

55. Kolodgie, F.D.; Burke, A.P.; Farb, A.; Gold, H.K.; Yuan, J.; Narula, J.; Finn, A.V.; Virmani, R. The thin-cap fibroatheroma: A type of vulnerable plaque: The major precursor lesion to acute coronary syndromes. Curr. Opin. Cardiol. 2001, 16, 285-292. [CrossRef] [PubMed]

56. Petersen, A.M.; Pedersen, B.K. The anti-inflammatory effect of exercise. J. Appl. Physiol. 2005, 98, 1154-1162. [CrossRef] [PubMed]

57. Flynn, M.G.; McFarlin, B.K. Toll-like receptor 4: Link to the anti-inflammatory effects of exercise? Exerc. Sport Sci. Rev. 2006, 34, 176-181. [CrossRef] [PubMed]

58. Kawanishi, N.; Yano, H.; Yokogawa, Y.; Suzuki, K. Exercise training inhibits inflammation in adipose tissue via both suppression of macrophage infiltration and acceleration of phenotypic switching from M1 to M2 macrophages in high-fat-diet-induced obese mice. Exerc. Immunol. Rev. 2010, 16, 105-118. [PubMed]

59. Ouchi, N.; Parker, J.L.; Lugus, J.J.; Walsh, K. Adipokines in inflammation and metabolic disease. Nat. Rev. Immunol. 2011, 11, 85-97. [CrossRef] [PubMed]

60. Skinner, N.A.; MacIsaac, C.M.; Hamilton, J.A.; Visvanathan, K. Regulation of toll-like receptor (TLR)2 and TLR4 on CD14 ${ }^{\mathrm{dim}} \mathrm{CD} 16^{+}$monocytes in response to sepsis-related antigens. Clin. Exp. Immunol. 2005, 141, 270-278. [CrossRef] [PubMed]

61. Belge, K.U.; Dayyani, F.; Horelt, A.; Siedlar, M.; Frankenberger, M.; Frankenberger, B.; Espevik, T.; Ziegler-Heitbrock, L. The proinflammatory $\mathrm{CD} 14^{+} \mathrm{CD} 16^{+} \mathrm{DR}^{++}$monocytes are a major source of TNF. J. Immunol. 2002, 168, 3536-3542. [CrossRef] [PubMed]

62. Simpson, R.J.; McFarlin, B.K.; McSporran, C.; Spielmann, G.; o Hartaigh, B.; Guy, K. Toll-like receptor expression on classic and pro-inflammatory blood monocytes after acute exercise in humans. Brain Behav. Immun. 2009, 23, 232-239. [CrossRef] [PubMed]

63. Timmerman, K.L.; Flynn, M.G.; Coen, P.M.; Markofski, M.M.; Pence, B.D. Exercise training-induced lowering of inflammatory (CD14+CD16+) monocytes: A role in the anti-inflammatory influence of exercise? J. Leukoc. Biol. 2008, 84, 1271-1278. [CrossRef] [PubMed]

64. Kingwell, B.A. Nitric oxide-mediated metabolic regulation during exercise: Effects of training in health and CVD disease. FASEB J. 2000, 14, 1685-1696. [CrossRef] [PubMed]

65. Oliveira, M.; Gleeson, M. The influence of prolonged cycling on monocyte toll-like receptor 2 and 4 expression in healthy men. Eur. J. Appl. Physiol. 2010, 109, 251-257. [CrossRef] [PubMed]

66. Stewart, L.K.; Flynn, M.G.; Campbell, W.W.; Craig, B.A.; Robinson, J.P.; McFarlin, B.K.; Timmerman, K.L.; Coen, P.M.; Felker, J.; Talbert, E. Influence of exercise training and age on CD14+ cell-surface expression of toll-like receptor 2 and 4. Brain Behav. Immun. 2005, 19, 389-397. [CrossRef] [PubMed]

67. Stefano, G.B.; Prevot, V.; Cadet, P.; Dardik, I. Vascular pulsations stimulating nitric oxide release during cyclic exercise may benefit health: A molecular approach. Int. J. Mol. Med. 2001, 7, 119-129. [CrossRef] [PubMed]

68. Jiao, P.; Chen, Q.; Shah, S.; Du, J.; Tao, B.; Tzameli, I.; Yan, W.; Xu, H. Obesity-related upregulation of monocyte chemotactic factors in adipocytes: Involvement of nuclear factor- $\kappa \mathrm{B}$ and c-Jun NH2-terminal kinase pathways. Diabetes 2009, 58, 104-115. [CrossRef] [PubMed]

69. Gautier, E.L.; Jakubzizk, C.; Randolph, G.J. Regulation of the migration and survival of monocytes subsets by chemokine receptors and its relevance to atheroscelorosis. Arterioscler. Thromb. Vasc. Biol. 2009, 29, 1412-1418. [CrossRef] [PubMed]

70. Xu, H.; Barnes, G.T.; Yang, Q.; Tan, G.; Yang, D.; Chou, C.J.; Sole, J.; Nichols, A.; Ross, J.S.; Tartaglia, L.A.; et al. Chronic inflammation in fat plays a crucial role in the development of obesity-related insulin resistance. J. Clin. Investig. 2003, 112, 1821-1830. [CrossRef] [PubMed] 
71. Bosanska, L.; Michalsky, D.; Lacinova, Z.; Dostalova, I.; Bartlova, M.; Haluzikova, D.; Matoulek, M.; Kasalicky, M.; Haluzik, M. The influence of obesity and different fat depots on adipose tissue gene expression and protein levels of cell adhesion molecules. Physiol. Res. 2010, 59, 79-88. [PubMed]

72. Chow, F.Y.; Nikolic-Paterson, D.J.; Ozols, E.; Atkins, R.C.; Tesch, G.H. Intercellular adhesion molecule-1 deficiency is protective against nephropathy in type 2 diabetic $\mathrm{db} / \mathrm{db}$ mice. J. Am. Soc. Nephrol. 2005, 16, 1711-1722. [CrossRef] [PubMed]

73. Lumeng, C.N.; Bodzin, J.L.; Saltiel, A.R. Obesity induces a phenotypic switch in adipose tissue macrophage polarization. J. Clin. Investig. 2007, 117, 175-184. [CrossRef] [PubMed]

74. Yakeu, G.; Butcher, L.; Isa, S.; Webb, R.; Roberts, A.W.; Thomas, A.W.; Backx, K.; James, P.E.; Morris, K. Low-intensity exercise enhances expression of markers of alternative activation in circulating leukocytes: Roles of PPAR $\gamma$ and Th2 cytokines. Atherosclerosis 2010, 212, 668-673. [CrossRef] [PubMed]

75. Stranahan, A.M.; Lee, K.; Mattson, M.P. Central mechanisms of HPA axis regulation by voluntary exercise. Neuromol. Med. 2008, 10, 118-127. [CrossRef] [PubMed]

76. Deuster, P.A.; Chrousos, G.P.; Luger, A.; DeBolt, J.E.; Bernier, L.L.; Trostmann, U.H.; Kyle, S.B.; Montgomery, L.C.; Loriaux, D.L. Hormonal and metabolic responses of untrained, moderately trained, and highly trained men to three exercise intensities. Metab. Clin. Exp. 1989, 38, 141-148. [CrossRef]

77. Schon, H.-T.; Weiskirchen, R. Exercise-Induced Release of Pharmacologically Active Substances and Their Relevance for Therapy of Hepatic Injury. Front. Pharmacol. 2016, 7, 283. [CrossRef] [PubMed]

78. Elenkov, I.J.; Chrousos, G.P. Stress hormones, proinflammatory and antiinflammatory cytokines, and autoimmunity. Ann. N. Y. Acad. Sci. 2002, 966, 290-303. [CrossRef] [PubMed]

79. Bostrom, P.; Wu, J.; Jedrychowski, M.P.; Korde, A.; Ye, L.; Lo, J.C.; Rasbach, K.A.; Bostrom, E.A.; Choi, J.H.; Long, J.Z.; et al. A PGC1- $\alpha$-dependent myokine that drives brown-fat-like development of white fat and thermogenesis. Nature 2012, 481, 463-468. [CrossRef] [PubMed]

80. Zhang, Y.; Li, R.; Meng, Y.; Li, S.; Donelan, W.; Zhao, Y.; Qi, L.; Zhang, M.; Wang, X.; Cui, T.; et al. Irisin stimulates browning of white adipocytes through mitogen-activated protein kinase p38 MAP kinase and ERK MAP kinase signaling. Diabetes 2014, 63, 514-525. [CrossRef] [PubMed]

81. Lee, P.; Linderman, J.D.; Smith, S.; Brychta, R.J.; Wang, J.; Idelson, C.; Perron, R.M.; Werner, C.D.; Phan, G.Q.; Kammula, U.S.; et al. Irisin and FGF21 are cold-induced endocrine activators of brown fat function in humans. Cell Metab. 2014, 19, 302-309. [CrossRef] [PubMed]

82. Zhang, Y.; Mu, Q.; Zhou, Z.; Song, H.; Zhang, Y.; Wu, F.; Jiang, M.; Wang, F.; Zhang, W.; Li, L.; et al. Protective Effect of Irisin on Atherosclerosis via Suppressing Oxidized Low Density Lipoprotein Induced Vascular Inflammation and Endothelial Dysfunction. PLoS ONE 2016, 11, e0158038. [CrossRef] [PubMed]

83. Zhang, Y.; Song, H.; Zhang, Y.; Wu, F.; Mu, Q.; Jiang, M.; Wang, F.; Zhang, W.; Li, L.; Shao, L.; et al. Irisin Inhibits Atherosclerosis by Promoting Endothelial Proliferation Through microRNA126-5p. J. Am. Heart Assoc. 2016, 5, e004031. [CrossRef] [PubMed]

84. Lu, J.; Xiang, G.; Liu, M.; Mei, W.; Xiang, L.; Dong, J. Irisin protects against endothelial injury and ameliorates atherosclerosis in apolipoprotein E-null diabetic mice. Atherosclerosis 2015, 243, 438-448. [CrossRef] [PubMed]

85. Qiu, S.; Cai, X.; Sun, Z.; Schumann, U.; Zugel, M.; Steinacker, J.M. Chronic exercise training and circulating irisin in adults: A meta-analysis. Sports Med. 2015, 45, 1577-1588. [CrossRef] [PubMed]

86. Hecksteden, A.; Wegmann, M.; Steffen, A.; Kraushaar, J.; Morsch, A.; Ruppenthal, S.; Kaestner, L.; Meyer, T. Irisin and exercise training in humans-Results from a randomized controlled training trial. BMC Med. 2013, 11, 235. [CrossRef] [PubMed]

87. Daskalopoulou, S.S.; Cooke, A.B.; Gomez, Y.H.; Mutter, A.F.; Filippaios, A.; Mesfum, E.T.; Mantzoros, C.S. Plasma irisin levels progressively increase in response to increasing exercise workloads in young, healthy, active subjects. Eur. J. Endocrinol. 2014, 171, 343-352. [CrossRef] [PubMed]

88. Moienneia, N.; Hosseini, S.R.A. Acute and chronic responses of metabolic myokine to different intensities of exercise in sedentary young women. Obes. Med. 2016, 1, 15-20. [CrossRef]

89. Ost, M.; Coleman, V.; Kasch, J.; Klaus, S. Regulation of myokine expression: Role of exercise and cellular stress. Free Radic. Biol. Med. 2016, 98, 78-89. [CrossRef] [PubMed]

90. Winn, N.C.; Grunewald, Z.I.; Liu, Y.; Heden, T.D.; Nyhoff, L.M.; Kanaley, J.A. Plasma irisin modestly increases during moderate and high-intensity afternoon exercise in obese females. PLoS ONE 2017, 12, e0170690. [CrossRef] [PubMed] 
91. Tsuchiya, Y.; Ando, D.; Takamatsu, K.; Goto, K. Resistance exercise induces a greater irisin response than endurance exercise. Metabolism 2015, 64, 1042-1050. [CrossRef] [PubMed]

92. Mazaki-Tovi, S.; Kanety, H.; Sivan, E. Adiponectin and human pregnancy. Curr. Diabetes Rep. 2005, 5, $278-281$. [CrossRef]

93. Okamoto, M.; Ohara-Imaizumi, M.; Kubota, N.; Hashimoto, S.; Eto, K.; Kanno, T.; Kubota, T.; Wakui, M.; Nagai, R.; Noda, M.; et al. Adiponectin induces insulin secretion in vitro and in vivo at a low glucose concentration. Diabetologia 2008, 51, 827-835. [CrossRef] [PubMed]

94. Yoon, M.J.; Lee, G.Y.; Chung, J.J.; Ahn, Y.H.; Hong, S.H.; Kim, J.B. Adiponectin increases fatty acid oxidation in skeletal muscle cells by sequential activation of AMP-activated protein kinase, p38 mitogen-activated protein kinase, and peroxisome proliferator-activated receptor $\alpha$. Diabetes 2006, 55, 2562-2570. [CrossRef] [PubMed]

95. Okamoto, Y.; Kihara, S.; Ouchi, N.; Nishida, M.; Arita, Y.; Kumada, M.; Ohashi, K.; Sakai, N.; Shimomura, I.; Kobayashi, H.; et al. Adiponectin reduces atherosclerosis in apolipoprotein E-deficient mice. Circulation 2002, 106, 2767-2770. [CrossRef] [PubMed]

96. Ferguson, M.A.; White, L.J.; McCoy, S.; Kim, H.W.; Petty, T.; Wilsey, J. Plasma adiponectin response to acute exercise in healthy subjects. Eur. J. Appl. Physiol. 2004, 91, 324-329. [CrossRef] [PubMed]

97. Punyadeera, C.; Zorenc, A.H.; Koopman, R.; McAinch, A.J.; Smit, E.; Manders, R.; Keizer, H.A.; Cameron-Smith, D.; van Loon, L.J. The effects of exercise and adipose tissue lipolysis on plasma adiponectin concentration and adiponectin receptor expression in human skeletal muscle. Eur. J. Endocrinol. 2005, 152, 427-436. [CrossRef] [PubMed]

98. Bouassida, A.; Chamari, K.; Zaouali, M.; Feki, Y.; Zbidi, A.; Tabka, Z. Review on leptin and adiponectin responses and adaptations to acute and chronic exercise. Br. J. Sports Med. 2010, 44, 620-630. [CrossRef] [PubMed]

99. Ouchi, N.; Walsh, K. Adiponectin as an anti-inflammatory factor. Clin. Chim. Acta 2006, 380, 24-30. [CrossRef] [PubMed]

100. Villarreal-Molina, M.T.; Antuna-Puente, B. Adiponectin: Anti-inflammatory and cardioprotective effects. Biochimie 2012, 94, 2143-2149. [CrossRef] [PubMed]

101. Hopkins, T.A.; Ouchi, N.; Shibata, R.; Walsh, K. Adiponectin actions in the CVD system. Cardiovasc. Res. 2007, 74, 11-18. [CrossRef] [PubMed]

102. Zhu, W.; Cheng, K.K.; Vanhoutte, P.M.; Lam, K.S.; Xu, A. Vascular effects of adiponectin: Molecular mechanisms and potential therapeutic intervention. Clin. Sci. 2008, 114, 361-374. [CrossRef] [PubMed]

103. Simpson, K.A.; Singh, M.A. Effects of exercise on adiponectin: A systematic review. Obesity 2008, 16, $241-256$. [CrossRef] [PubMed]

104. Marcell, T.J.; McAuley, K.A.; Traustadottir, T.; Reaven, P.D. Exercise training is not associated with improved levels of C-reactive protein or adiponectin. Metabolism 2005, 54, 533-541. [CrossRef] [PubMed]

105. Jamurtas, A.Z.; Theocharis, V.; Koukoulis, G.; Stakias, N.; Fatouros, I.G.; Kouretas, D.; Koutedakis, Y. The effects of acute exercise on serum adiponectin and resistin levels and their relation to insulin sensitivity in overweight males. Eur. J. Appl. Physiol. 2006, 97, 122-126. [CrossRef] [PubMed]

106. De Mello, M.T.; de Piano, A.; Carnier, J.; Sanches Pde, L.; Correa, F.A.; Tock, L.; Ernandes, R.M.; Tufik, S.; Damaso, A.R. Long-term effects of aerobic plus resistance training on the metabolic syndrome and adiponectinemia in obese adolescents. J. Clin. Hypertens. 2011, 13, 343-350. [CrossRef] [PubMed]

107. Simpson, R.J.; Hammacher, A.; Smith, D.K.; Matthews, J.M.; Ward, L.D. Interleukin-6: Structure-function relationships. Protein Sci. 1997, 6, 929-955. [CrossRef] [PubMed]

108. Pedersen, B.K.; Steensberg, A.; Schjerling, P. Muscle-derived interleukin-6: Possible biological effects. J. Physiol. 2001, 536, 329-337. [CrossRef] [PubMed]

109. Scheller, J.; Chalaris, A.; Schmidt-Arras, D.; Rose-John, S. The pro- and anti-inflammatory properties of the cytokine interleukin-6. Biochim. Biophys. Acta 2011, 1813, 878-888. [CrossRef] [PubMed]

110. Peters, M.; Jacobs, S.; Ehlers, M.; Vollmer, P.; Mullberg, J.; Wolf, E.; Brem, G.; Meyer zum Buschenfelde, K.H.; Rose-John, S. The function of the soluble interleukin 6 (IL-6) receptor in vivo: Sensitization of human soluble IL-6 receptor transgenic mice towards IL-6 and prolongation of the plasma half-life of IL-6. J. Exp. Med. 1996, 183, 1399-1406. [CrossRef] [PubMed] 
111. Becker, C.; Fantini, M.C.; Schramm, C.; Lehr, H.A.; Wirtz, S.; Nikolaev, A.; Burg, J.; Strand, S.; Kiesslich, R.; Huber, S.; et al. TGF- $\beta$ suppresses tumor progression in colon cancer by inhibition of IL- 6 trans-signaling. Immunity 2004, 21, 491-501. [CrossRef] [PubMed]

112. Chen, Q.; Fisher, D.T.; Clancy, K.A.; Gauguet, J.M.; Wang, W.C.; Unger, E.; Rose-John, S.; von Andrian, U.H.; Baumann, H.; Evans, S.S. Fever-range thermal stress promotes lymphocyte trafficking across high endothelial venules via an interleukin 6 trans-signaling mechanism. Nat. Immunol. 2006, 7, 1299-1308. [CrossRef] [PubMed]

113. Mullberg, J.; Schooltink, H.; Stoyan, T.; Gunther, M.; Graeve, L.; Buse, G.; Mackiewicz, A.; Heinrich, P.C.; Rose-John, S. The soluble interleukin-6 receptor is generated by shedding. Eur. J. Immunol. 1993, 23, 473-480.

114. Lust, J.A.; Donovan, K.A.; Kline, M.P.; Greipp, P.R.; Kyle, R.A.; Maihle, N.J. Isolation of an mRNA encoding a soluble form of the human interleukin-6 receptor. Cytokine 1992, 4, 96-100. [CrossRef]

115. Taga, T.; Hibi, M.; Hirata, Y.; Yamasaki, K.; Yasukawa, K.; Matsuda, T.; Hirano, T.; Kishimoto, T. Interleukin-6 triggers the association of its receptor with a possible signal transducer, gp130. Cell 1989, 58, 573-581. [CrossRef]

116. Frisdal, E.; Lesnik, P.; Olivier, M.; Robillard, P.; Chapman, M.J.; Huby, T.; Guerin, M.; Le Goff, W. Interleukin-6 protects human macrophages from cellular cholesterol accumulation and attenuates the proinflammatory response. J. Biol. Chem. 2011, 286, 30926-30936. [CrossRef] [PubMed]

117. Schieffer, B.; Selle, T.; Hilfiker, A.; Hilfiker-Kleiner, D.; Grote, K.; Tietge, U.J.; Trautwein, C.; Luchtefeld, M.; Schmittkamp, C.; Heeneman, S.; et al. Impact of interleukin-6 on plaque development and morphology in experimental atherosclerosis. Circulation 2004, 110, 3493-3500. [CrossRef] [PubMed]

118. Hou, T.; Tieu, B.C.; Ray, S.; Recinos Iii, A.; Cui, R.; Tilton, R.G.; Brasier, A.R. Roles of IL-6-gp130 Signaling in Vascular Inflammation. Curr. Cardiol. Rev. 2008, 4, 179-192. [CrossRef] [PubMed]

119. Kraakman, M.J.; Kammoun, H.L.; Allen, T.L.; Deswaerte, V.; Henstridge, D.C.; Estevez, E.; Matthews, V.B.; Neill, B.; White, D.A.; Murphy, A.J.; et al. Blocking IL-6 trans-signaling prevents high-fat diet-induced adipose tissue macrophage recruitment but does not improve insulin resistance. Cell Metab. 2015, 3, 403-416. [CrossRef] [PubMed]

120. Schuett, H.; Oestreich, R.; Waetzig, G.H.; Annema, W.; Luchtefeld, M.; Hillmer, A.; Bavendiek, U.; von Felden, J.; Divchev, D.; Kempf, T.; et al. Transsignaling of interleukin-6 crucially contributes to atherosclerosis in mice. Arterioscler. Thromb. Vasc. Biol. 2012, 32, 281-290. [CrossRef] [PubMed]

121. Lacroix, M.; Rousseau, F.; Guilhot, F.; Malinge, P.; Magistrelli, G.; Herren, S.; Jones, S.A.; Jones, G.W.; Scheller, J.; Lissilaa, R.; et al. Novel insights into IL-6 cis- and trans-signaling pathways by differentially manipulating the assembly of the IL-6 signaling complex. J. Biol. Chem. 2015, 6, 26943-26953. [CrossRef] [PubMed]

122. Iida, O.; Yokoi, H.; Soga, Y.; Inoue, N.; Suzuki, K.; Yokoi, Y.; Kawasaki, D.; Zen, K.; Urasawa, K.; Shintani, Y.; et al. Cilostazol reduces angiographic restenosis after endovascular therapy for femoropopliteal lesions in the sufficient treatment of peripheral intervention by cilostazol study. Circulation 2013, 127, 2307-2315. [CrossRef] [PubMed]

123. Morieri, M.L.; Passaro, A.; Zuliani, G. Interleukin-6 “Trans-Signaling" and Ischemic Vascular Disease: The Important Role of Soluble gp130. Med. Inflamm. 2017, 2017, 1396398. [CrossRef] [PubMed]

124. Pedersen, B.K. Special feature for the Olympics: Effects of exercise on the immune system: Exercise and cytokines. Immunol. Cell Biol. 2000, 78, 532-535. [CrossRef] [PubMed]

125. Ostrowski, K.; Rohde, T.; Zacho, M.; Asp, S.; Pedersen, B.K. Evidence that IL-6 is produced in skeletal muscle during intense long-term muscle activity. J. Physiol. 1998, 508, 949-953. [CrossRef] [PubMed]

126. Ostrowski, K.; Rohde, T.; Asp, S.; Schjerling, P.; Pedersen, B.K. Pro- and anti-inflammatory cytokine balance in strenuous exercise in humans. J. Physiol. 1999, 515, 287-291. [CrossRef] [PubMed]

127. Ostrowski, K.; Hermann, C.; Bangash, A.; Schjerling, P.; Nielsen, J.N.; Pedersen, B.K. A trauma-like elevation of plasma cytokines in humans in response to treadmill running. J. Physiol. 1998, 513, 889-894. [CrossRef] [PubMed]

128. Sprenger, H.; Jacobs, C.; Nain, M.; Gressner, A.M.; Prinz, H.; Wesemann, W.; Gemsa, D. Enhanced release of cytokines, interleukin-2 receptors, and neopterin after long-distance running. Clin. Immunol. Immunopathol. 1992, 63, 188-195. [CrossRef]

129. Rohde, T.; MacLean, D.A.; Richter, E.A.; Kiens, B.; Pedersen, B.K. Prolonged submaximal eccentric exercise is associated with increased levels of plasma IL-6. Am. J. Physiol. 1997, 273, E85-E91. [PubMed] 
130. Cullen, T.; Thomas, A.W.; Webb, R.; Hughes, M.G. Interleukin-6 and associated cytokine responses to an acute bout of high-intensity interval exercise: The effect of exercise intensity and volume. Appl. Physiol. Nutr. Metab. 2016, 41, 803-808. [CrossRef] [PubMed]

131. Fischer, C.P. Interleukin-6 in acute exercise and training: What is the biological relevance? Exerc. Immunol. Rev. 2006, 12, 6-33. [PubMed]

132. Vicenova, B.; Vopalensky, V.; Burysek, L.; Pospisek, M. Emerging role of interleukin-1 in CVD diseases. Physiol. Res. 2009, 58, 481-498. [PubMed]

133. Banda, N.K.; Guthridge, C.; Sheppard, D.; Cairns, K.S.; Muggli, M.; Bech-Otschir, D.; Dubiel, W.; Arend, W.P. Intracellular IL-1 receptor antagonist type 1 inhibits IL-1-induced cytokine production in keratinocytes through binding to the third component of the COP9 signalosome. J. Immunol. 2005, 174, 3608-3616. [CrossRef] [PubMed]

134. Dewberry, R.M.; King, A.R.; Crossman, D.C.; Francis, S.E. Interleukin-1 receptor antagonist (IL-1ra) modulates endothelial cell proliferation. FEBS Lett. 2008, 582, 886-890. [CrossRef] [PubMed]

135. Bhaskar, V.; Yin, J.; Mirza, A.M.; Phan, D.; Vanegas, S.; Issafras, H.; Michelson, K.; Hunter, J.J.; Kantak, S.S. Monoclonal antibodies targeting IL-1 $\beta$ reduce biomarkers of atherosclerosis in vitro and inhibit atherosclerotic plaque formation in apolipoprotein E-deficient mice. Atherosclerosis 2011, 216, 313-320. [CrossRef] [PubMed]

136. Goto, H.; Ishihara, Y.; Kikuchi, T.; Izawa, A.; Ozeki, N.; Okabe, E.; Kamiya, Y.; Ozawa, Y.; Mizutani, H.; Yamamoto, G.; et al. Interleukin-1 Receptor Antagonist Has a Novel Function in the Regulation of Matrix Metalloproteinase-13 Expression. PLoS ONE 2015, 10, e0140942. [CrossRef] [PubMed]

137. Dinarello, C.A.; Thompson, R.C. Blocking IL-1: Interleukin 1 receptor antagonist in vivo and in vitro. Immunol. Today 1991, 12, 404-410. [CrossRef]

138. Porreca, E.; di Febbo, C.; Barbacane, R.C.; Panara, M.R.; Cuccurullo, F.; Conti, P. Effect of interleukin-1 receptor antagonist on vascular smooth muscle cell proliferation. Atherosclerosis 1993, 99, 71-78. [CrossRef]

139. Devlin, C.M.; Kuriakose, G.; Hirsch, E.; Tabas, I. Genetic alterations of IL-1 receptor antagonist in mice affect plasma cholesterol level and foam cell lesion size. Proc. Natl. Acad. Sci. USA 2002, 99, 6280-6285. [CrossRef] [PubMed]

140. Abbate, A.; van Tassell, B.W.; Biondi-Zoccai, G.G. Blocking interleukin-1 as a novel therapeutic strategy for secondary prevention of CVD events. BioDrugs 2012, 26, 217-233. [CrossRef] [PubMed]

141. Dewberry, R.; Holden, H.; Crossman, D.; Francis, S. Interleukin-1 receptor antagonist expression in human endothelial cells and atherosclerosis. Arterioscler. Thromb. Vasc. Biol. 2000, 20, 2394-2400. [CrossRef] [PubMed]

142. Isoda, K.; Ohsuzu, F. The effect of interleukin-1 receptor antagonist on arteries and cholesterol metabolism. J. Atheroscler. Thromb. 2006, 13, 21-30. [CrossRef] [PubMed]

143. Ronsen, O.; Lea, T.; Bahr, R.; Pedersen, B.K. Enhanced plasma IL-6 and IL-1ra responses to repeated vs. Single bouts of prolonged cycling in elite athletes. J. Appl. Physiol. 2002, 92, 2547-2553. [CrossRef] [PubMed]

144. Drenth, J.P.; van Uum, S.H.; van Deuren, M.; Pesman, G.J.; van der Ven-Jongekrijg, J.; van der Meer, J.W. Endurance run increases circulating IL- 6 and IL-1ra but downregulates ex vivo TNF- $\alpha$ and IL-1 $\beta$ production. J. Appl. Physiol. 1995, 79, 1497-1503. [PubMed]

145. Calle, M.C.; Fernandez, M.L. Effects of resistance training on the inflammatory response. Nutr. Res. Pract. 2010, 4, 259-269. [CrossRef] [PubMed]

146. Izquierdo, M.; Ibanez, J.; Calbet, J.A.; Navarro-Amezqueta, I.; Gonzalez-Izal, M.; Idoate, F.; Hakkinen, K.; Kraemer, W.J.; Palacios-Sarrasqueta, M.; Almar, M.; et al. Cytokine and hormone responses to resistance training. Eur. J. Appl. Physiol. 2009, 107, 397-409. [CrossRef] [PubMed]

147. Forti, L.N.; van Roie, E.; Njemini, R.; Coudyzer, W.; Beyer, I.; Delecluse, C.; Bautmans, I. Effects of resistance training at different loads on inflammatory markers in young adults. Eur. J. Appl. Physiol. 2017, 117, 511-519. [CrossRef] [PubMed]

148. Back, M.; Hansson, G.K. Anti-inflammatory therapies for atherosclerosis. Nat. Rev. Cardiol. 2015, $12,199-211$. [CrossRef] [PubMed]

149. Moubayed, S.P.; Heinonen, T.M.; Tardif, J.C. Anti-inflammatory drugs and atherosclerosis. Curr. Opin. Lipidol. 2007, 18, 638-644. [CrossRef] [PubMed]

150. Berman, J.P.; Farkouh, M.E.; Rosenson, R.S. Emerging anti-inflammatory drugs for atherosclerosis. Expert Opin. Emerg. Drugs 2013, 18, 193-205. [CrossRef] [PubMed] 
151. Bergheanu, S.C.; Bodde, M.C.; Jukema, J.W. Pathophysiology and treatment of atherosclerosis: Current view and future perspective on lipoprotein modification treatment. Neth. Heart J. 2017, 25, 231-242. [CrossRef] [PubMed]

152. Klingenberg, R.; Hansson, G.K. Treating inflammation in atherosclerotic CVD disease: Emerging therapies. Eur. Heart J. 2009, 30, 2838-2844. [CrossRef] [PubMed]

153. Cutolo, M.; Sulli, A.; Pizzorni, C.; Seriolo, B.; Straub, R.H. Anti-inflammatory mechanisms of methotrexate in rheumatoid arthritis. Ann. Rheum. Dis. 2001, 60, 729-735. [CrossRef] [PubMed]

154. Westlake, S.L.; Colebatch, A.N.; Baird, J.; Kiely, P.; Quinn, M.; Choy, E.; Ostor, A.J.; Edwards, C.J. The effect of methotrexate on CVD disease in patients with rheumatoid arthritis: A systematic literature review. Rheumatology 2010, 49, 295-307. [CrossRef] [PubMed]

155. Micha, R.; Imamura, F.; Wyler von Ballmoos, M.; Solomon, D.H.; Hernan, M.A.; Ridker, P.A.; Mozaffarian, D. Systematic review and meta-analysis of methotrexate use and risk of CVD disease. Am. J. Cardiol. 2011, 108, 1362-1370. [CrossRef] [PubMed]

156. Moreira, D.M.; Vieira, J.L.; Gottschall, C.A. The effects of methotrexate therapy on the physical capacity of patients with ischemic heart failure: A randomized double-blind, placebo-controlled trial (METIS trial). J. Card. Fail. 2009, 15, 828-834. [CrossRef] [PubMed]

157. Everett, B.M.; Pradhan, A.D.; Solomon, D.H.; Paynter, N.; Macfadyen, J.; Zaharris, E.; Gupta, M.; Clearfield, M.; Libby, P.; Hasan, A.A.; et al. Rationale and Design of the CVD Inflammation Reduction Trial (CIRT): A Test of the Inflammatory Hypothesis of Atherothrombosis. Am. Heart J. 2013, 166, 199-207. [CrossRef] [PubMed]

158. Nuki, G. Colchicine: Its mechanism of action and efficacy in crystal-induced inflammation. Curr. Rheumatol. Rep. 2008, 10, 218-227. [CrossRef] [PubMed]

159. Crittenden, D.B.; Lehmann, R.A.; Keenan, R.T.; Shah, B.; Greenberg, J.D.; Cronstein, B.N.; Sedlis, S.P.; Pillinger, M.H. Colchicine use is associated with decreased prevalence of myocardial infarction in patients with gout. J. Rheumatol. 2012, 39, 1458-1464. [CrossRef] [PubMed]

160. Deftereos, S.; Giannopoulos, G.; Angelidis, C.; Alexopoulos, N.; Filippatos, G.; Papoutsidakis, N.; Sianos, G.; Goudevenos, J.; Alexopoulos, D.; Pyrgakis, V.; et al. Anti-inflammatory treatment with colchicine in acute myocardial infarction: A pilot study. Circulation 2015, 132, 1395-1403. [CrossRef] [PubMed]

161. Nidorf, S.M.; Eikelboom, J.W.; Budgeon, C.A.; Thompson, P.L. Low-dose colchicine for secondary prevention of CVD disease. J. Am. Coll. Cardiol. 2013, 61, 404-410. [CrossRef] [PubMed]

162. Ridker, P.M.; Thuren, T.; Zalewski, A.; Libby, P. Interleukin-1 $\beta$ inhibition and the prevention of recurrent CVD events: Rationale and design of the canakinumab anti-inflammatory thrombosis outcomes study (cantos). Am. Heart J. 2011, 162, 597-605. [CrossRef] [PubMed]

163. Higgins, P.; Dawson, J.; Lees, K.R.; McArthur, K.; Quinn, T.J.; Walters, M.R. Xanthine oxidase inhibition for the treatment of CVD disease: A systematic review and meta-analysis. Cardiovasc. Ther. 2012, 30, 217-226. [CrossRef] [PubMed]

164. George, J.; Carr, E.; Davies, J.; Belch, J.J.; Struthers, A. High-dose allopurinol improves endothelial function by profoundly reducing vascular oxidative stress and not by lowering uric acid. Circulation 2006, 114, 2508-2516. [CrossRef] [PubMed]

165. Kushiyama, A.; Okubo, H.; Sakoda, H.; Kikuchi, T.; Fujishiro, M.; Sato, H.; Kushiyama, S.; Iwashita, M.; Nishimura, F.; Fukushima, T.; et al. Xanthine oxidoreductase is involved in macrophage foam cell formation and atherosclerosis development. Arterioscler. Thromb. Vasc. Biol. 2012, 32, 291-298. [CrossRef] [PubMed]

166. Kanbay, M.; Solak, Y.; Gaipov, A.; Takir, M.; Weiner, D.E. Allopurinol as a Kidney-Protective, Cardioprotective, and Antihypertensive Agent: Hype or Reality? Blood Purif. 2014, 37, 172-178. [CrossRef] [PubMed]

167. Jacobsson, L.T.; Turesson, C.; Gulfe, A.; Kapetanovic, M.C.; Petersson, I.F.; Saxne, T.; Geborek, P. Treatment with tumor necrosis factor blockers is associated with a lower incidence of first CVD events in patients with rheumatoid arthritis. J. Rheumatol. 2005, 32, 1213-1218. [PubMed]

168. Popa, C.; Netea, M.G.; Radstake, T.; van der Meer, J.W.; Stalenhoef, A.F.; van Riel, P.L.; Barerra, P. Influence of anti-tumour necrosis factor therapy on CVD risk factors in patients with active rheumatoid arthritis. Ann. Rheum. Dis. 2005, 64, 303-305. [CrossRef] [PubMed] 
169. Morton, A.C.; Rothman, A.M.; Greenwood, J.P.; Gunn, J.; Chase, A.; Clarke, B.; Hall, A.S.; Fox, K.; Foley, C.; Banya, W.; et al. The effect of interleukin-1 receptor antagonist therapy on markers of inflammation in non-ST elevation acute coronary syndromes: The MRC-ILA heart study. Eur. Heart J. 2015, 36, 377-384. [CrossRef] [PubMed]

170. Ridker, P.M.; Howard, C.P.; Walter, V.; Everett, B.; Libby, P.; Hensen, J.; Thuren, T.; Group, C.P.I. Effects of interleukin-1 $\beta$ inhibition with canakinumab on hemoglobin A1c, lipids, C-reactive protein, interleukin-6, and fibrinogen: A phase IIb randomized, placebo-controlled trial. Circulation 2012, 126, 2739-2748. [CrossRef] [PubMed]

171. Tzellos, T.; Kyrgidis, A.; Trigoni, A.; Zouboulis, C.C. Association of ustekinumab and briakinumab with major adverse CVD events: An appraisal of meta-analyses and industry sponsored pooled analyses to date. Dermatoendocrinol 2012, 4, 320-323. [CrossRef] [PubMed]

172. Gilbert, J.; Lekstrom-Himes, J.; Donaldson, D.; Lee, Y.; Hu, M.; Xu, J.; Wyant, T.; Davidson, M.; MLN1202 Study Group. Effect of CC chemokine receptor 2 CCR2 blockade on serum C-reactive protein in individuals at atherosclerotic risk and with a single nucleotide polymorphism of the monocyte chemoattractant protein-1 promoter region. Am. J. Cardiol. 2011, 107, 906-911. [CrossRef] [PubMed]

173. Weber, C.; Meiler, S.; Doring, Y.; Koch, M.; Drechsler, M.; Megens, R.T.; Rowinska, Z.; Bidzhekov, K.; Fecher, C.; Ribechini, E.; et al. Ccl17-expressing dendritic cells drive atherosclerosis by restraining regulatory $\mathrm{t}$ cell homeostasis in mice. J. Clin. Investig. 2011, 121, 2898-2910. [CrossRef] [PubMed]

174. Shaposhnik, Z.; Wang, X.; Trias, J.; Fraser, H.; Lusis, A. The synergistic inhibition of atherogenesis in ApoE $^{-/-}$mice between pravastatin and the sPLA2 inhibitor varespladib (A-002). J. Lipid Res. 2009, 50, 623-629. [CrossRef] [PubMed]

175. Fraser, H.; Hislop, C.; Christie, R.M.; Rick, H.L.; Reidy, C.A.; Chouinard, M.L.; Eacho, P.I.; Gould, K.E.; Trias, J. Varespladib (a-002), a secretory phospholipase a2 inhibitor, reduces atherosclerosis and aneurysm formation in ApoE ${ }^{-/-}$mice. J. Cardiovasc. Pharmacol. 2009, 53, 60-65. [CrossRef] [PubMed]

176. Rosenson, R.S.; Hislop, C.; Elliott, M.; Stasiv, Y.; Goulder, M.; Waters, D. Effects of varespladib methyl on biomarkers and major CVD events in acute coronary syndrome patients. J. Am. Coll. Cardiol. 2010, 56, 1079-1088. [CrossRef] [PubMed]

177. Nicholls, S.J.; Kastelein, J.J.; Schwartz, G.G.; Bash, D.; Rosenson, R.S.; Cavender, M.A.; Brennan, D.M.; Koenig, W.; Jukema, J.W.; Nambi, V.; et al. Varespladib and CVD events in patients with an acute coronary syndrome: The vista-16 randomized clinical trial. JAMA 2014, 311, 252-262. [CrossRef] [PubMed]

178. Ait-Oufella, H.; Herbin, O.; Lahoute, C.; Coatrieux, C.; Loyer, X.; Joffre, J.; Laurans, L.; Ramkhelawon, B.; Blanc-Brude, O.; Karabina, S.; et al. Group X secreted phospholipase A2 limits the development of atherosclerosis in LDL receptor-null mice. Arterioscler. Thromb. Vasc. Biol. 2013, 33, 466-473. [CrossRef] [PubMed]

179. Wilensky, R.L.; Shi, Y.; Mohler, E.R., 3rd; Hamamdzic, D.; Burgert, M.E.; Li, J.; Postle, A.; Fenning, R.S.; Bollinger, J.G.; Hoffman, B.E.; et al. Inhibition of lipoprotein-associated phospholipase A2 reduces complex coronary atherosclerotic plaque development. Nat. Med. 2008, 14, 1059-1066. [CrossRef] [PubMed]

180. Serruys, P.; Garcia-Garcia, H.M.; Buszman, P.; Erne, P.; Verheye, S.; Aschermann, M.; Duckers, H.; Bleie, O.; Dudek, D.; Botker, H.E.; et al. Effects of the direct lipoprotein-associated phospholipase A2 inhibitor darapladib on human coronary atherosclerotic plaque. Circulation 2008, 118, 1172-1182. [CrossRef] [PubMed]

181. Investigators, S.; White, H.D.; Held, C.; Stewart, R.; Tarka, E.; Brown, R.; Davies, R.Y.; Budaj, A.; Harrington, R.A.; Steg, P.G.; et al. Darapladib for preventing ischemic events in stable coronary heart disease. N. Engl. J. Med. 2014, 370, 1702-1711. [CrossRef] [PubMed]

182. O'Donoghue, M.L.; Braunwald, E.; White, H.D.; Lukas, M.A.; Tarka, E.; Steg, P.G.; Hochman, J.S.; Bode, C.; Maggioni, A.P.; Im, K.; et al. Effect of darapladib on major coronary events after an acute coronary syndrome: The SOLID-TIMI 52 randomized clinical trial. JAMA 2014, 312, 1006-1015. [CrossRef] [PubMed]

183. Capra, V.; Back, M.; Angiolillo, D.J.; Cattaneo, M.; Sakariassen, K.S. Impact of vascular thromboxane prostanoid receptor activation on hemostasis, thrombosis, oxidative stress, and inflammation. J. Thromb. Haemost. 2014, 12, 126-137. [CrossRef] [PubMed]

184. Huang, E.S.; Strate, L.L.; Ho, W.W.; Lee, S.S.; Chan, A.T. Long Term Use of Aspirin and the Risk of Gastrointestinal Bleeding. Am. J. Med. 2011, 124, 426-433. [CrossRef] [PubMed] 
185. Bousser, M.G.; Amarenco, P.; Chamorro, A.; Fisher, M.; Ford, I.; Fox, K.M.; Hennerici, M.G.; Mattle, H.P.; Rothwell, P.M.; de Cordoue, A.; et al. Terutroban versus aspirin in patients with cerebral ischaemic events (perform): A randomised, double-blind, parallel-group trial. Lancet 2011, 377, 2013-2022. [CrossRef]

186. Nissen, S.E.; Yeomans, N.D.; Solomon, D.H.; Luscher, T.F.; Libby, P.; Husni, M.E.; Graham, D.Y.; Borer, J.S.; Wisniewski, L.M.; Wolski, K.E.; et al. CVD safety of celecoxib, naproxen, or ibuprofen for arthritis. N. Engl. J. Med. 2016, 375, 2519-2529. [CrossRef] [PubMed]

187. Sondergaard, K.B.; Weeke, P.; Wissenberg, M.; Olsen, A.M.S.; Fosbol, E.L.; Lippert, F.K.; Torp-Pedersen, C.; Gislason, G.H.; Folke, F. Non-steroidal anti-inflammatory drug use is associated with increased risk of out-of-hospital cardiac arrest: A nationwide case-time-control study. Eur. Heart J. Cardiovasc. Pharmacother. 2017, 3, 100-107. [CrossRef] [PubMed]

188. Jawien, J.; Gajda, M.; Rudling, M.; Mateuszuk, L.; Olszanecki, R.; Guzik, T.J.; Cichocki, T.; Chlopicki, S.; Korbut, R. Inhibition of five lipoxygenase activating protein (FLAP) by MK-886 decreases atherosclerosis in ApoE/LDLR-double knockout mice. Eur. J. Clin. Investig. 2006, 36, 141-146. [CrossRef] [PubMed]

189. Hakonarson, H.; Thorvaldsson, S.; Helgadottir, A.; Gudbjartsson, D.; Zink, F.; Andresdottir, M.; Manolescu, A.; Arnar, D.O.; Andersen, K.; Sigurdsson, A.; et al. Effects of a 5-lipoxygenase-activating protein inhibitor on biomarkers associated with risk of myocardial infarction: A randomized trial. JAMA 2005, 293, 2245-2256. [CrossRef] [PubMed]

190. Tardif, J.C.; L'Allier, P.L.; Ibrahim, R.; Gregoire, J.C.; Nozza, A.; Cossette, M.; Kouz, S.; Lavoie, M.A.; Paquin, J.; Brotz, T.M.; et al. Treatment with 5-lipoxygenase inhibitor via-2291 (atreleuton) in patients with recent acute coronary syndrome. Circ. Cardiovasc. Imaging 2010, 3, 298-307. [CrossRef] [PubMed]

191. Ridker, P.M.; Rifai, N.; Pfeffer, M.A.; Sacks, F.; Braunwald, E. Long-term effects of pravastatin on plasma concentration of C-reactive protein. The cholesterol and recurrent events (care) investigators. Circulation 1999, 100, 230-235. [CrossRef] [PubMed]

192. Shepherd, J.; Cobbe, S.M.; Ford, I.; Isles, C.G.; Lorimer, A.R.; MacFarlane, P.W.; McKillop, J.H.; Packard, C.J. Prevention of coronary heart disease with pravastatin in men with hypercholesterolemia. West of Scotland Coronary Prevention Study Group. N. Engl. J. Med. 1995, 333, 1301-1307. [CrossRef] [PubMed]

193. Ridker, P.M.; Rifai, N.; Clearfield, M.; Downs, J.R.; Weis, S.E.; Miles, J.S.; Gotto, A.M., Jr.; Air Force/Texas Coronary Atherosclerosis Prevention Study Investigators. Measurement of C-reactive protein for the targeting of statin therapy in the primary prevention of acute coronary events. N. Engl. J. Med. 2001, 344, 1959-1965. [CrossRef] [PubMed]

194. The Scandinavian Simvastatin Survival. Randomised trial of cholesterol lowering in 4444 patients with coronary heart disease: The Scandinavian Simvastatin Survival Study (4S). Lancet 1994, 344, 1383-1389.

195. Ridker, P.M.; Cannon, C.P.; Morrow, D.; Rifai, N.; Rose, L.M.; McCabe, C.H.; Pfeffer, M.A.; Braunwald, E.; Pravastatin or Atorvastatin Evaluation and Infection Therapy-Thrombolysis in Myocardial Infarction Investigators. C-reactive protein levels and outcomes after statin therapy. N. Engl. J. Med. 2005, 352, 20-28. [CrossRef] [PubMed]

196. Nissen, S.E.; Nicholls, S.J.; Sipahi, I.; Libby, P.; Raichlen, J.S.; Ballantyne, C.M.; Davignon, J.; Erbel, R.; Fruchart, J.C.; Tardif, J.C.; et al. Effect of very high-intensity statin therapy on regression of coronary atherosclerosis: the ASTEROID trial. JAMA 2006, 295, 1556-1565. [CrossRef] [PubMed]

197. Nicholls, S.J.; Ballantyne, C.M.; Barter, P.J.; Chapman, M.J.; Erbel, R.M.; Libby, P.; Raichlen, J.S.; Uno, K.; Borgman, M.; Wolski, K.; et al. Effect of two intensive statin regimens on progression of coronary disease. N. Engl. J. Med. 2011, 365, 2078-2087. [CrossRef] [PubMed]

198. Ridker, P.M.; Danielson, E.; Fonseca, F.A.; Genest, J.; Gotto, A.M., Jr.; Kastelein, J.J.; Koenig, W.; Libby, P.; Lorenzatti, A.J.; MacFadyen, J.G.; et al. Rosuvastatin to prevent vascular events in men and women with elevated C-reactive protein. N. Engl. J. Med. 2008, 359, 2195-2207. [CrossRef] [PubMed]

199. Tsujita, K.; Sugiyama, S.; Sumida, H.; Shimomura, H.; Yamashita, T.; Yamanaga, K.; Komura, N.; Sakamoto, K.; Oka, H.; Nakao, K.; et al. Impact of dual lipid-lowering strategy with ezetimibe and atorvastatin on coronary plaque regression in patients with percutaneous coronary intervention: The multicenter randomized controlled PRECISE-IVUS trial. J. Am. Coll. Cardiol. 2015, 66, 495-507. [CrossRef] [PubMed]

200. Cannon, C.P.; Blazing, M.A.; Giugliano, R.P.; McCagg, A.; White, J.A.; Theroux, P.; Darius, H.; Lewis, B.S.; Ophuis, T.O.; Jukema, J.W.; et al. Ezetimibe added to Statin therapy after acute coronary syndromes. N. Engl. J. Med. 2015, 372, 2387-2397. [CrossRef] [PubMed] 
201. Catapano, A.L.; Graham, I.; de Backer, G.; Wiklund, O.; Chapman, M.J.; Drexel, H.; Hoes, A.W.; Jennings, C.S.; Landmesser, U.; Pedersen, T.R.; et al. ESC/EAS Guidelines for the Management of Dyslipidaemias: The Task Force for the Management of Dyslipidaemias of the European Society of Cardiology (ESC) and European Atherosclerosis Society (EAS). Developed with the special contribution of the European Assocciation for CVD Prevention \& Rehabilitation (EACPR). Eur. Heart J. 2016, 37, 2999. [PubMed]

202. Sabatine, M.S.; Giugliano, R.P.; Wiviott, S.D.; Raal, F.J.; Blom, D.J.; Robinson, J.; Ballantyne, C.M.; Somaratne, R.; Legg, J.; Wasserman, S.M.; et al. Efficacy and safety of evolocumab in reducing lipids and CVD events. N. Engl. J. Med. 2015, 372, 1500-1509. [CrossRef] [PubMed]

203. Robinson, J.G.; Farnier, M.; Krempf, M.; Bergeron, J.; Luc, G.; Averna, M.; Stroes, E.S.; Langslet, G.; Raal, F.J.; Shahawy, M.E.; et al. Efficacy and safety of alirocumab in reducing lipids and CVD events. N. Engl. J. Med. 2015, 372, 1489-1499. [CrossRef] [PubMed]

204. Nicholls, S.J.; Puri, R.; Anderson, T.; Ballantyne, C.M.; Cho, L.; Kastelein, J.J.; Koenig, W.; Somaratne, R.; Kassahun, H.; Yang, J.; et al. Effect of Evolocumab on progression of coronary disease in statin-treated patients: The GLAGOV randomized clinical trial. JAMA 2016, 316, 2373-2384. [CrossRef] [PubMed]

205. Kotwal, S.; Jun, M.; Sullivan, D.; Perkovic, V.; Neal, B. w3 Fatty acids and CVD outcomes: Systematic review and meta-analysis. Circ. Cardiovasc. Qual. Outcomes 2012, 5, 808-818. [CrossRef] [PubMed]

206. Barter, P.J.; Caulfield, M.; Eriksson, M.; Grundy, S.M.; Kastelein, J.J.; Komajda, M.; Lopez-Sendon, J.; Mosca, L.; Tardif, J.C.; Waters, D.D.; et al. Effects of torcetrapib in patients at high risk for coronary events. N. Engl. J. Med. 2007, 357, 2109-2122. [CrossRef] [PubMed]

207. Schwartz, G.G.; Olsson, A.G.; Abt, M.; Ballantyne, C.M.; Barter, P.J.; Brumm, J.; Chaitman, B.R.; Holme, I.M.; Kallend, D.; Leiter, L.A.; et al. Effects of dalcetrapib in patients with a recent acute coronary syndrome. N. Engl. J. Med. 2012, 367, 2089-2099. [CrossRef] [PubMed]

208. Nicholls, S.J.; Lincoff, A.M.; Barter, P.J.; Brewer, H.B.; Fox, K.A.; Gibson, C.M.; Grainger, C.; Menon, V.; Montalescot, G.; Rader, D.; et al. Assessment of the clinical effects of cholesteryl ester transfer protein inhibition with evacetrapib in patients at high-risk for vascular outcomes: Rationale and design of the ACCELERATE trial. Am. Heart J. 2015, 170, 1061-1069. [CrossRef] [PubMed]

209. Seeger, F.H.; Sedding, D.; Langheinrich, A.C.; Haendeler, J.; Zeiher, A.M.; Dimmeler, S. Inhibition of the p38 map kinase in vivo improves number and functional activity of vasculogenic cells and reduces atherosclerotic disease progression. Basic Res. Cardiol. 2010, 105, 389-397. [CrossRef] [PubMed]

210. Sarov-Blat, L.; Morgan, J.M.; Fernandez, P.; James, R.; Fang, Z.; Hurle, M.R.; Baidoo, C.; Willette, R.N.; Lepore, J.J.; Jensen, S.E.; et al. Inhibition of p38 mitogen-activated protein kinase reduces inflammation after coronary vascular injury in humans. Arterioscler. Thromb. Vasc. Biol. 2010, 30, 2256-2263. [CrossRef] [PubMed]

211. Cheriyan, J.; Webb, A.J.; Sarov-Blat, L.; Elkhawad, M.; Wallace, S.M.; Maki-Petaja, K.M.; Collier, D.J.; Morgan, J.; Fang, Z.; Willette, R.N.; et al. Inhibition of p38 mitogen-activated protein kinase improves nitric oxide-mediated vasodilatation and reduces inflammation in hypercholesterolemia. Circulation 2011, 123, 515-523. [CrossRef] [PubMed]

212. Elkhawad, M.; Rudd, J.H.; Sarov-Blat, L.; Cai, G.; Wells, R.; Davies, L.C.; Collier, D.J.; Marber, M.S.; Choudhury, R.P.; Fayad, Z.A.; et al. Effects of p38 mitogen-activated protein kinase inhibition on vascular and systemic inflammation in patients with atherosclerosis. JACC Cardiovasc. Imaging 2012, 5, 911-922. [CrossRef] [PubMed]

213. Melloni, C.; Sprecher, D.L.; Sarov-Blat, L.; Patel, M.R.; Heitner, J.F.; Hamm, C.W.; Aylward, P.; Tanguay, J.F.; DeWinter, R.J.; Marber, M.S.; et al. The study of losmapimod treatment on inflammation and infarctsize (solstice): Design and rationale. Am. Heart J. 2012, 164, 646-653.e3. [CrossRef] [PubMed]

214. Newby, L.K.; Marber, M.S.; Melloni, C.; Sarov-Blat, L.; Aberle, L.H.; Aylward, P.E.; Cai, G.; de Winter, R.J.; Hamm, C.W.; Heitner, J.F.; et al. Losmapimod, a novel p38 mitogen-activated protein kinase inhibitor, in non-ST-segment elevation myocardial infarction: A randomised phase 2 trial. Lancet 2014, 384, 1187-1195. [CrossRef]

215. Judkins, C.P.; Diep, H.; Broughton, B.R.; Mast, A.E.; Hooker, E.U.; Miller, A.A.; Selemidis, S.; Dusting, G.J.; Sobey, C.G.; Drummond, G.R. Direct evidence of a role for Nox2 in superoxide production, reduced nitric oxide bioavailability, and early atherosclerotic plaque formation in $\mathrm{ApoE}^{-/-}$mice. Am. J. Physiol. Heart Circ. Physiol. 2010, 298, H24-H32. [CrossRef] [PubMed] 
216. Gray, S.P.; di Marco, E.; Okabe, J.; Szyndralewiez, C.; Heitz, F.; Montezano, A.C.; de Haan, J.B.; Koulis, C.; El-Osta, A.; Andrews, K.L.; et al. Nadph oxidase 1 plays a key role in diabetes mellitus-accelerated atherosclerosis. Circulation 2013, 127, 1888-1902. [CrossRef] [PubMed]

217. Takase, H.; Hashimoto, A.; Okutsu, R.; Hirose, Y.; Ito, H.; Imaizumi, T.; Miyakoda, G.; Mori, T. Anti-atherosclerotic effect of cilostazol in apolipoprotein-e knockout mice. Arzneimittelforschung 2007, 57, 185-191. [CrossRef] [PubMed]

218. Souness, J.E.; Hassall, G.A.; Parrott, D.P. Inhibition of pig aortic smooth muscle cell DNA synthesis by selective type III and type IV cyclic amp phosphodiesterase inhibitors. Biochem. Pharmacol. 1992, 44, 857-866. [CrossRef]

219. Ishizaka, N.; Taguchi, J.; Kimura, Y.; Ikari, Y.; Aizawa, T.; Togo, M.; Miki, K.; Kurokawa, K.; Ohno, M. Effects of a single local administration of cilostazol on neointimal formation in balloon-injured rat carotid artery. Atherosclerosis 1999, 142, 41-46. [CrossRef]

220. Beghe, B.; Rabe, K.F.; Fabbri, L.M. Phosphodiesterase-4 inhibitor therapy for lung diseases. Am. J. Respir. Crit. Care Med. 2013, 188, 271-278. [CrossRef] [PubMed]

221. White, W.B.; Cooke, G.E.; Kowey, P.R.; Calverley, P.M.; Bredenbroker, D.; Goehring, U.M.; Zhu, H.; Lakkis, H.; Mosberg, H.; Rowe, P.; et al. CVD safety in patients receiving roflumilast for the treatment of COPD. Chest 2013, 144, 758-765. [CrossRef] [PubMed]

222. Balarini, C.M.; Leal, M.A.; Gomes, I.B.; Pereira, T.M.; Gava, A.L.; Meyrelles, S.S.; Vasquez, E.C. Sildenafil restores endothelial function in the apolipoprotein E knockout mouse. J. Transl. Med. 2013, 11, 3. [CrossRef] [PubMed]

223. Tardif, J.C.; McMurray, J.J.; Klug, E.; Small, R.; Schumi, J.; Choi, J.; Cooper, J.; Scott, R.; Lewis, E.F.; L'Allier, P.L.; et al. Effects of succinobucol (AGI-1067) after an acute coronary syndrome: A randomised, double-blind, placebo-controlled trial. Lancet 2008, 371, 1761-1768. [CrossRef]

224. Tardif, J.C.; Gregoire, J.; L'Allier, P.L.; Ibrahim, R.; Anderson, T.J.; Reeves, F.; Title, L.M.; Schampaert, E.; LeMay, M.; Lesperance, J.; et al. Effects of the antioxidant succinobucol (agi-1067) on human atherosclerosis in a randomized clinical trial. Atherosclerosis 2008, 197, 480-486. [CrossRef] [PubMed]

225. Libby, P.; Warner, S.J.; Friedman, G.B. Interleukin 1: A mitogen for human vascular smooth muscle cells that induces the release of growth-inhibitory prostanoids. J. Clin. Investig. 1988, 81, 487-498. [CrossRef] [PubMed]

226. Back, M.; Hansson, G.K. Leukotriene receptors in atherosclerosis. Ann. Med. 2006, 38, 493-502. [CrossRef] [PubMed]

227. Harris, J.M.; Chess, R.B. Effect of pegylation on pharmaceuticals. Nat. Rev. Drug Discov. 2003, 2, $214-221$. [CrossRef] [PubMed]

228. Jazayeri, J.A.; Carroll, G.J. Fc-based cytokines: Prospects for engineering superior therapeutics. BioDrugs 2008, 22, 11-26. [CrossRef] [PubMed]

229. Whitham, M.; Febbraio, M.A. The ever-expanding myokinome: Discovery challenges and therapeutic implications. Nat. Rev. Drug Discov. 2016, 15, 719-729. [CrossRef] [PubMed]

230. Turecek, P.L.; Bossard, M.J.; Schoetens, F.; Ivens, I.A. Pegylation of biopharmaceuticals: A review of chemistry and nonclinical safety information of approved drugs. J. Pharm. Sci. 2016, 105, 460-475. [CrossRef] [PubMed]

231. Uhlen, M.; Fagerberg, L.; Hallstrom, B.M.; Lindskog, C.; Oksvold, P.; Mardinoglu, A.; Sivertsson, A.; Kampf, C.; Sjostedt, E.; Asplund, A.; et al. Tissue-based map of the human proteome. Science 2015, 347, 1260419. [CrossRef] [PubMed]

232. Panyam, J.; Labhasetwar, V. Biodegradable nanoparticles for drug and gene delivery to cells and tissue. Adv. Drug Deliv. Rev. 2003, 55, 329-347. [CrossRef]

(C) 2017 by the authors. Licensee MDPI, Basel, Switzerland. This article is an open access article distributed under the terms and conditions of the Creative Commons Attribution (CC BY) license (http:/ / creativecommons.org/licenses/by/4.0/). 